\title{
Small Oil-Free Bearings
}

\author{
Hobart S. White
}

\begin{abstract}
An investigation was made of materials that may be suitable for use as oil-free bearings in aircraft clocks and similar instruments between $-55^{\circ}$ and $+70^{\circ} \mathrm{C}$, to replace lubricated jewels that do not give satisfactory operation at subzero temperatures because of congealing of the oil. Another advantage of an oil-free instrument is the freedom from cleaning and oiling periodically during shelf storage. Materials included in the investigation were plasties, plastics with fillers, impregnated metals, and impregnated carbon. Friction tests were made with an inclined-plane type of static-friction apparatus, and with shafts rotating in loaded journal bearings, at temperatures from $-55^{\circ}$ to $+70^{\circ} \mathrm{C}$. With bearings of typical materials stored on steel shafts, the effect of shelf storage on static friction was investigated. Wear tests were made with loaded bearings on $1 / 4$-inch-diameter rotating shafts made of different types of steel. With oscillating 1/8-inch-diameter shafts and 1,000-gram loads, wear data were obtained on bearings of the more promising materials. Using an endstone wear testing machine, wear data were obtained for end-thrust bearings made of typical bearing materials. The performance of oil-free bearings in 18 timepieces was investigated.
\end{abstract}

\section{Introduction}

It is essential that aircraft instruments and devices operate satisfactorily over a wide temperature range. At subzero temperatures, increased viscosity and congealing of lubricating oils result in high friction with lubricated bearings. In aircraft clocks, similar jeweled instruments, and some mechanical fuzing devices, the power supplied for normal operation is not sufficient to overcome the excessively high friction at low temperatures. Some devices may be made to operate at low temperatures by having a surplus of power supplied, but this is not feasible in timepiece mechanisms. The nonspreading watch and clock oils conventionally used for lubricating jewel (sapphire) bearings are not satisfactory at $-50^{\circ} \mathrm{C}$, and at ordinary temperatures the necessity of periodic cleaning and oiling during shelf storage and during service is not desirable.

Because of the unsatisfactory performance of lubricated aircraft clocks at low temperatures, a project ${ }^{1}$ was initiated to investigate materials that may be suitable for use as oil-free bearings in timepieces, between $-55^{\circ}$ and $+70^{\circ} \mathrm{C}$. to replace jewels that require lubrication. In addition to the primary obiective of satisfactory operation at low temperature, another important advantage of an oil-free timepiece is freedom from, cleaning and oiling periodically during shelf storage.

Bearing materials included in the investigation were plastics, plastics with fillers, impregnated metals, and impregnated carbon. Corrosion-resistant shaft materials were investigated. The work consisted of investigations of the friction and the wear characteristics of the materials, and trial of $t$ he more promising materials in timepieces. \footnotetext{
1 This project was initiated in October 1951, and was sponsored by the Bureau
of Aeronauties, Department of the Navy.
}

\section{Bearing Materials}

The bearing materials tested are identified by sample number and composition in table 1 . The percentages given are approximate; they are computed either from the densities of the samples and the densities of the ingredients, or from the composition of the suspension or dispersion as given by the manufacturer in conjunction with the known amount of fillers added. In some cases the samples from commercial firms are specially prepared materials; in other cases they are products that the manufacturers considered promising for the application.

For convenience, the abbreviations PTFE and PTFCE are used in this paper to symbolize polytetrafluoroethylene and polytrifluorochloroethylene, respectively.

\subsection{Plastics}

The low-friction characteristics of PTFE (polytetrafluoroethylene) were largely responsible for the inception of this project. This resin [1] $]^{2}$ is waxy in appearance, and white or gray in color, except that thin sheets are transparent. It is a crystalline solid with good stability from $-320^{\circ}$ to $+500^{\circ} \mathrm{F}$, and is chemically inert to known reagents and solvents except molten alkaline metals and gaseous fluorine under pressure. Its relative softness and poor heat conductivity limit its suitability as a bearing material to applications involving low speeds and low unit pressures.

The PTFCE (polytrifluorochloroethylene) used in this investigation is a relatively hard thermoplastic, with good stability from $-320^{\circ}$ to $+375^{\circ} \mathrm{F}$. It is chemically inert to most organic solvents and reagents. It may vary from the amorphous to the crystalline state, depending largely on the rate of cooling in its preparation [2]. The amorphous material is transparent; and crystalline material is

Figures in brackets indicate the literature references at the end of this paper. 
TABLE 1.-Bearing material

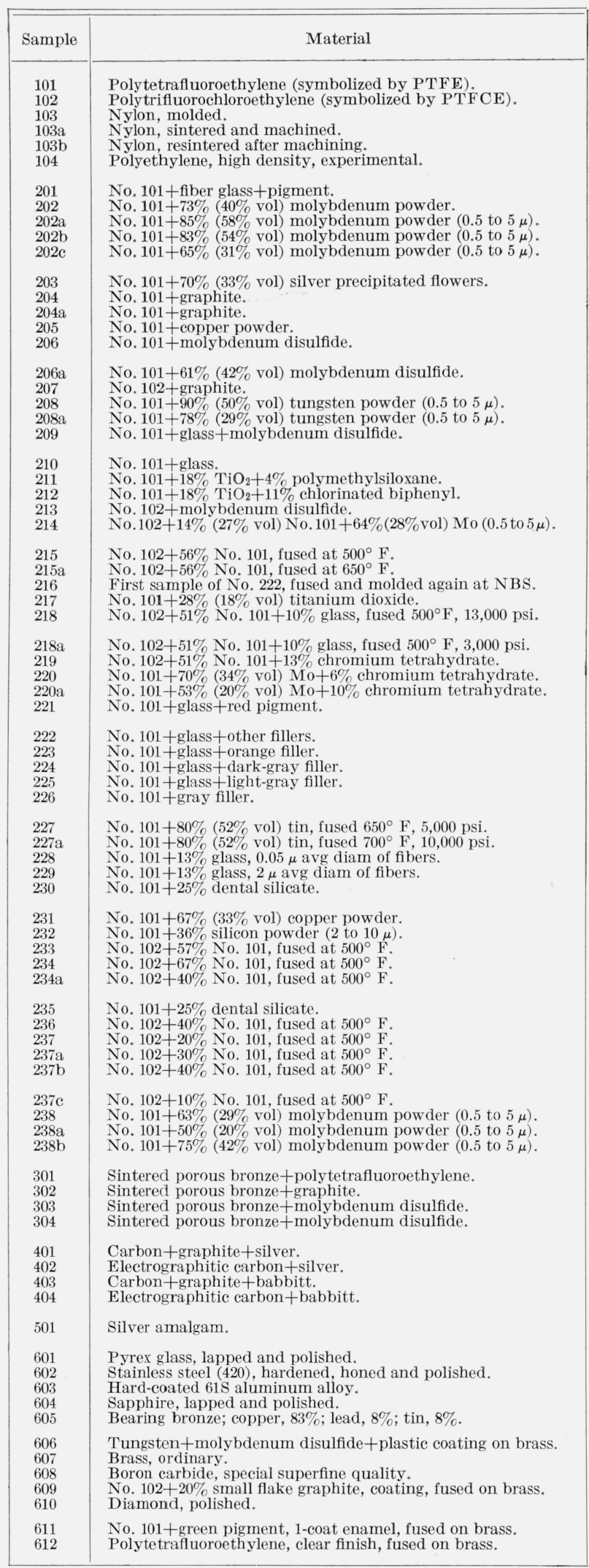

translucent, and is harder than the amorphous and more resistant to cold flow and heat distortion. Neither form has the low-friction characteristics of PTFE at ordinary temperatures.

The nylon material used in these tests was of the hardest type, and has been used to some extent for bearings and gears in certain applications. This material normally contains water; the amount of water varies with the ambient temperature, humidity, and time of exposure, but frequently is between 1 and 4 percent. The friction is not exceptionally low.

The high-density polyethylene tested was a relatively new type of polyethylene plastic produced by a commercial firm for experimental purposes. It is characterized by higher molding temperatures and greater strengths than those of ordinary polyethylene.

\subsection{Plastics With Fillers}

Because of the relative softness of PTFE, it is logical to expect that its load-carrying ability and its wear resistance might be improved by the addition of suitable fillers. Accordingly, several fillers were tried in combination with this plastic, including graphite, molybdenum disulfide, fiber glass, dental silicate, silicon, titanium dioxide, silver, copper, tungsten, and molybdenum.

Samples 202, 202a, 202b, 202c, 203, 204, 106a, 208, 208a, 214, 217, 227, 227a, 230, 231, and 232 were prepared (at the Bureau) by adding the filler in powder form to PTFE clear finish-type suspension (in water) and stirring to make a uniform paste. In general, after drying to the consistency of a very stiff paste, these samples were molded in to cylinders, which were then more completely dried on a hotplate or by heating in the mold. To fuse the PTFE, the samples were dried and then heated to about $700^{\circ} \mathrm{F}$ at a pressure of about 10,000 psi in a heavy-walled steel tube with a loose-fitting steel rod at each end. Samples 211, 212, 228, 229, and 235 were prepared in a similar manner, except that they were thoroughly mixed in a blender after the addition of acetone in quantities sufficient to provide suitable fluidity for the blending action. After blending the samples, much of the acetone was removed by decanting, some was removed by pressing with absorbent paper and by compressing in the hands in the manner used for forming snowballs, and then the mixtures were dried by heating as above. Samples 238, 238a, and $238 \mathrm{~b}$ were prepared as above, except that PTFE aqueous dispersion, designated by the manufacturer as TD-3, was used instead of the PTFE clear finishtype suspension; and samples 220 and 220a were prepared in a similar manner with PTFE one-coat enamel-type suspension instead of the clear finishtype suspension.

PTFCE was tried also as a resin binder with different fillers, such as graphite, molybdenum disulfide, and PTFE. Sample 215 was prepared by mixing PTFE clear finish-type suspension with PTFCE dispersion (in xylol) and then blending after dilution with acetone. After the drying operation, this sample was heated in the heavy-walled tube to about $500^{\circ} \mathrm{F}$ at a pressure of about 5,000 psi to fuse 
the PTFCE. A trial at higher temperatures, to fuse the PTFE also, resulted in an inferior product because of decomposition of the PTFCE (sample $215 \mathrm{a}$ at $650^{\circ} \mathrm{F}$ ). Samples 234 and $234 \mathrm{a}$ were prepared by adding PTFCE powder to PTFE clear finish and blending after the addition of acetone. In preparing sample 236 , PTFCE powder was added to TD-3 dispersion (PTFE) and the mixture was diluted with acetone. In preparing samples 237, $237 \mathrm{a}, 237 \mathrm{~b}$, and $237 \mathrm{c}$, the PTFCE powder was dispersed in acetone, and the dispersion was blended with TD-3 dispersion. Samples 214, 218, 218a, and 219 were prepared by methods similar to the above, except that they contained other fillers in addition to the PTFCE. Samples 214 and 233 were prepared by mixing in paste form, without the addition of acetone.

Samples 201, 204a, 205, 206, 207, 209, 210, 213, and 216 were commercial preparations of PTFE containing fillers. Examination of these with a 20power stereomicroscope disclosed pockets of pure plastic much larger than some of the journals in timepieces. Sample 221 was similar to sample 201, except that it was mixed by the dispersion method instead of the micropulverizing method. This resulted in a more uniform mixture of the PTFE in sample 221 than in 201, but examination with a 20-power stereomicroscope revealed that the mixture was not as uniform as is desirable for bearings with a 0.005 -in. bore. A few small pockets of glass without any binder were found in sample 221 . The uniformity of mixture in samples 222 to 226 was similar to that of sample 221, and it is believed that these commercial samples also were prepared by the dispersion method.

\subsection{Impregnated Bronze}

Porous bronze (not oil-impregnated) was impregnated with PTFE suspensoid by subjecting a dry degreased specimen of porous bronze to a vacuum of about $15 \mathrm{~mm}$ of mercury for about $10 \mathrm{~min}$. Then PTFE suspension was introduced to cover the specimen before the vacuum was released. The excess suspensoid was wiped from the surface, and the specimen was dried by heating to $400^{\circ} \mathrm{F}$. The cycle was repeated several times before finally fusing the plastic at about $700^{\circ} \mathrm{F}$. However, stereomicroscopic examination of the broken edge of a 0.19 -in. plate showed that the pores near the center were not filled with plastic, the impregnation being complete only near the surface.

Sample 302 of porous bronze, impregnated with graphite, and samples 303 and 304, impregnated with molybdenum disulfide, were obtained commercially. Samples 302 and 303 were prepared by the hot-press method.

\subsection{Impregnated Carbon}

Samples 401 and 403 were molded carbon-graphite mixtures that had been impregnated with molten silver and with molten babbitt, respectively, by a vacuum-pressure process. Likewise, samples 402 and 404 were electrographitic carbon impregnated with silver and with babbitt, respectively.

\subsection{Miscellaneous}

The silver amalgam (sample 501) was made from precipitated flowers of silver mixed with mercury with a mortar and pestle. The amalgam was compressed in a steel cylinder at about 10,000 psi to drive out excess mercury. This material was very brittle, and the edges of the hole chipped during the boring and reaming operation. An amalgam of dental-alloy filings (about 70 percent of silver in the alloy) was made similar to the above. This material was less brittle than the silver amalgam, but was not a satisfactory oil-free bearing material; hence the investigation of this type of material was soon discontinued.

Samples 601 (glass), 602 (420 stainless steel), and 604 (sapphire) were used mostly with lubricants for reference purposes. Sample 603 was an electrically anodized coating (essentially a sapphire coating) on an aluminum alloy. Sample 605 was a bearing bronze (in composition similar to SAE Nos. 64 and 660 copper-base casting alloy), and sample 607 was ordinary yellow brass. Sample 606 was a commercial coating material consisting of tungsten, molybdenum disulfide, and a plastic; the coating was applied to the bore of a brass bearing and baked $3 \mathrm{hrs}$ at $400^{\circ} \mathrm{F}$, in accordance with the instructions supplied with it. Boron carbide (sample 608) has a hardness between those of sapphire and of diamond (sample 610). Samples 609, 611, and 612 were coatings of PTFCE plus graphite, P'TFE one-coat enamel, and PTFE clear finish, respectively, fused on brass.

\section{Shaft Materials}

The shaft materials tested during this investigation are listed in table 2. The sample number in each case is the same as that used as type designations by the American Iron and Steel Institute (AISI), except for the cases of the cobalt alloy (C40) and the machinery steel (M), which are not listed by the manufacturer as meeting any AISI type.

The 303 steel was a free-machining chromiumnickel austenitic steel not capable of heat treatment, and commonly known as 18-8 steel. This was used chiefly for the wear-test shafts.

The 420 steel was a type used for cutlery, and may be heat-treated to a hardness of about 50 Rockwell C.

TABLE 2. Shaft materials

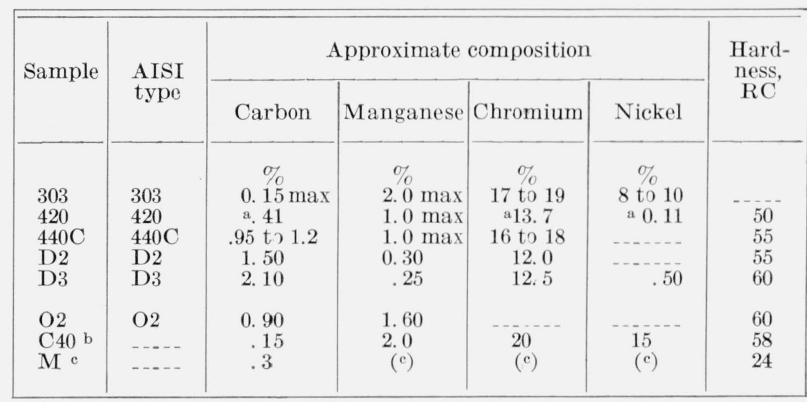

a From analysis; other values from SAE Handbook or from manufacturers type analysis.

A machinery steel described by the manufacturer as a special chrome vanadium alloy with small amounts of nickel and molybdenum. 
The $440 \mathrm{C}$ steel is described in various literature as having the greatest quenched hardness and wear resistance upon heat treatment of any corrosion- or heat-resistant steel.

The D2 steel was an air-hardening high-chromium tool steel having some corrosion resistance and good wear resistance in the hardened state. The D3 steel was similar, except that it was the oil-hardening type.

The $\mathrm{O} 2$ steel was an oil-hardening, nondeforming type, similar to that used for shafts in lubricated timepieces.

The cobalt-base alloy (C40) was a highly corrosion-resistant material of the type used for mainsprings in watches.

The machinery steel (M) was furnished in the heattreated condition and recommended as having good wear resistance.

\section{Apparatus}

The apparatus used in this investigation were selected or designed for making simple comparative tests of the friction and wear characteristics of oilfree bearing materials under conditions simulating those in service. Shafts $1 / 4 \mathrm{in}$. in diameter were used for friction and wear measurements to give reasonable accuracy under various conditions of speed and load, and still be in the range of application of small oilfree bearings. Wear tests were made with 1/8-in.diameter oscillating shafts as a compromise between ease of measuring the wear and the smallness of the oscillating shafts in timepieces. For shafts less than $1 / 8$ in. in diameter, timepieces were used for making comparative tests of the more promising materials.

\subsection{Static-Friction Machines}

An inclmed-plane type of apparatus was used for making the static-friction tests. The tangent of the angle with the horizon when a rider on the incline starts to slide is used as a measure of $f$, the coefficient of friction.

An apparatus of this type available at the start of this project has been described previously [3]. It consists essentially of a hotplate mounted between two journals, with provision for siow tilting. The plate specimen is clamped to the plane surface of the hotplate, which provides for tests at and above room temperature. A pointer indicates the angle of tilt on a calibrated scale.

The rider specimen is loaded by a rectangular yoke, through a point contact. An electric circuit is arranged so that with a slight movement the rider contacts a needle and lights a small signal lamp.

The plate specimens are 7 by 2 by $3 / 8$ in., and the riders are 2 by 1 by $1 / 2 \mathrm{in}$. The riders are undercut to leave a bearing surface 0.125 by 1 in. at each end, and have a cone-shaped depression in the center of the upper surface for contacting the point of the loading yoke.

A similar apparatus, without a hotplate, was constructed on a scale small enough to be operated within an insulated control box at low temperatures. The insulated box was constructed of plywood with a 3 -in. thickness of rock-wool insulation between the walls. The front of the box is removable to allow easy access, and windows are provided for readings during tests. An internal compartment contains a sirocco-type blower and space for dry ice or a heater, leaving an available working space 16 by 16 by 12 in.

\subsection{Bearing-Friction Test Machines}

A small friction-testing machine for use in the temperature-control box was constructed with two support ball bearings for mounting a test shaft with a journal for the test bearing at one end, and provision for driving at the other end. This outboardtest-bearing type of machine facilitates the changing of test bearings and minimizes the damage to the bores of the test bearings when sliding on and off the shaft. Measurements of the frictional torque are obtained from the displacement of a pendulum mounted on the test bearing housing. The load consists of the bearing housing plus the weight of the pendulum and bearing. The pendulum consists of a rod, a small bob, and a pointer that measures displacement from the center line on a suitable scale. The pendulum is calibrated in a horizontal position with the housing on a smooth horizontal surface, as indicated in figure 1 . The force, $R$, necessary to maintain it in a horizontal position is measured by a balance. If the weight of the pendulum acts at its center of gravity so that $W b=R a$, then $W=R a / b$. When the shaft is rotating, the friction torque is given by $W c=R a c / b$, and $a / b=d / c$. The friction torque, $W c,=R d$. The frictional torque may be found from the displacement reading multiplied by $R$, which is a constant for each pendulum. Likewise,

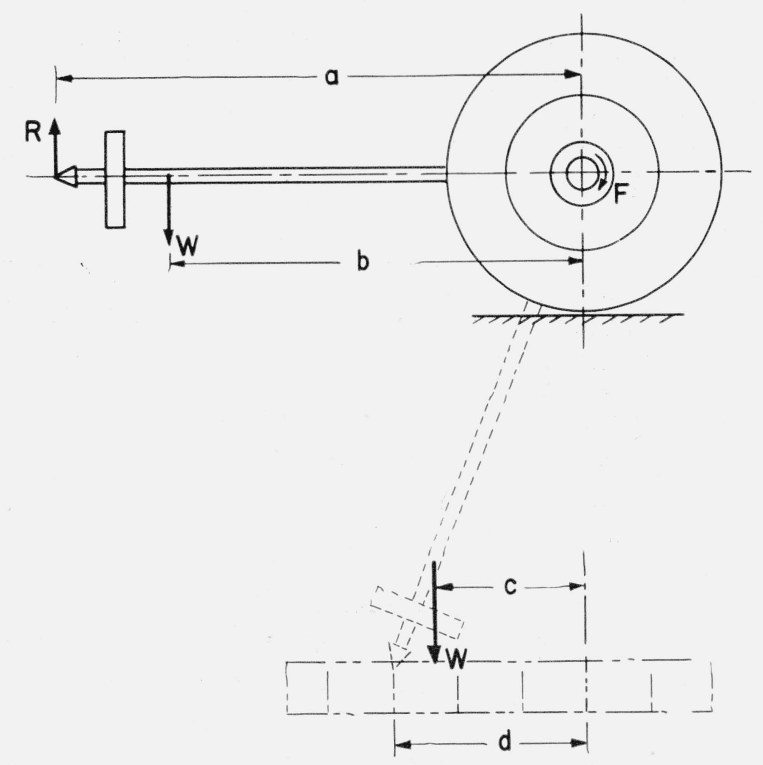

Figure 1. Diagrammatic shetch of friction torque measuring apparatus. 
for a given load and shaft diameter, the coefficient of friction may be computed from the displacement multiplied by the appropriate constant.

\subsection{Bearing-Wear Test Machines}

Two multiple-shaft speed-reducing units were modified to provide apparatus for studying wear with sleeve bearings on rotating journals. Steel test journals, $1 / 4$ in. in diameter, were made and fitted to the ends of the six horizontal output shafts on each unit. Steel housings and weights suspended from flexible wire provide suitable loads on the bearings, and motorized drives are used to obtain the desired speeds. Four shafts of one of these machines are shown on the left half in figure 2. The bearing assembly has been removed from one of the shafts, and is shown disassembled on the table. The collar has been removed from the third shaft from the right to show the end of a test bearing in place.

The wear patterns along the entire lengths of the bearings indicated that the flexible wires attached to the steel housings were suitable for applying the load, and that swivel yokes were not necessary for uniform loading.

For studying wear of sleeve bearings on oscillating journals, oscillating-shaft machines were made by modifying oscillating display motors. One of the oscillating-shaft wear machines is shown in figure 2 , clamped to the right end of the support of the above multiple shaft unit. A 2-lb weight attached with a wire plus the other moving parts provide a $1,000-\mathrm{g}$ load on the pair of bearings, which are housed in a yoke made from $1 / 8-i n$. by $1 / 2$-in. brass. One of the bearings may be seen directly above the upper end of the wire supporting the weight. The 1/8-in.diameter steel shaft passes through two brass collars, which are soldered to the yoke of the oscillating bar; a setscrew in one of the collars engages the shaft so that it oscillates with the oscillating arm. Attached

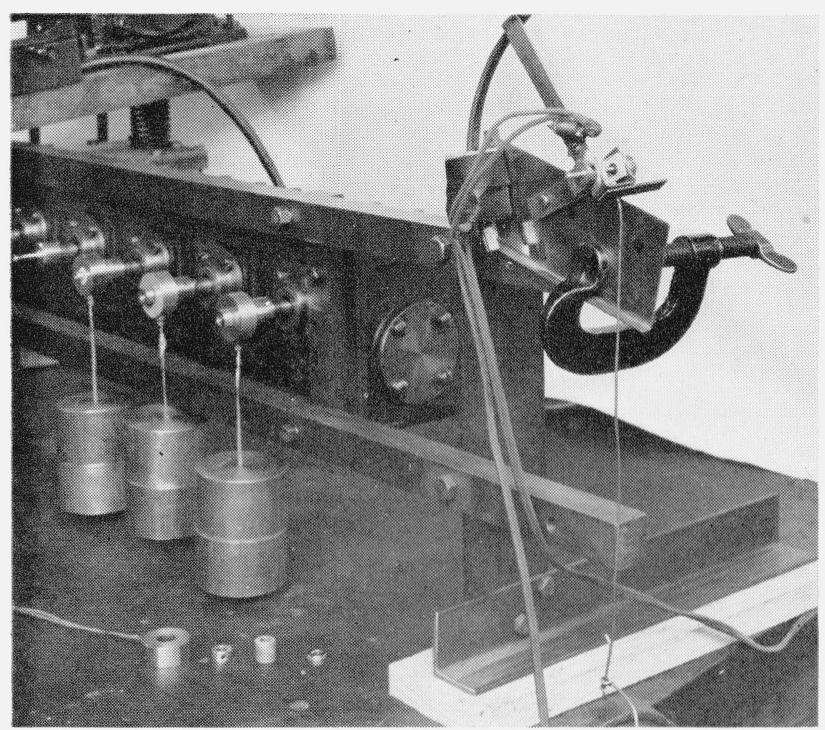

FIGURE 2. Journal-bearing wear-testing apparatus. to the outer end of the oscillating arm is a quadrant, which passes through a solenoid. A mercury-in-glass switch attached to the oscillating arm energizes the solenoid at the appropriate time to provide oscillating motion of the shaft-arm-quadrant assembly. Although the static load on the bearings is only $1,000 \mathrm{~g}$, the load during the impulse from the solenoid is considerably greater. The oscillatory surface speed and the impulse loading of the shaft simulate the conditions common to balance-staff journals in timepieces.

An apparatus was designed and built for making thrust-bearing-wear tests with oscillating shafts. This apparatus, designated as an endstone-wear testing machine, is shown in figure 3 . A motordriven connecting rod oscillates a shaft back and forth with a motion of about $87^{\circ}$; and this motion is doubled when transmitted to 4 vertical shafts, each of which has a 1/8-in.-diameter hole and setscrew at each end for attaching test-pin specimens. An endstone specimen in a $1,000-\mathrm{g}$ weight supplies a load on each top pin; a specimen at each lower pin supports the $1,000-\mathrm{g}$ weight plus the weight of the floating shaft and gear, or a total thrust load of $1,240 \mathrm{~g}$. One of the $1,000-\mathrm{g}$ weights has been removed and inverted to show the upper test pin and endstone specimen in the photograph. In operation, each weight is positioned coaxially with its test pin by means of four snug but free-fitting locating pins, and is prevented from rotating by means of a thin flexure spring. No vertical oscillation of the floating shaft was observed, and no effect of vertical forces from the gears was indicated in the test data.

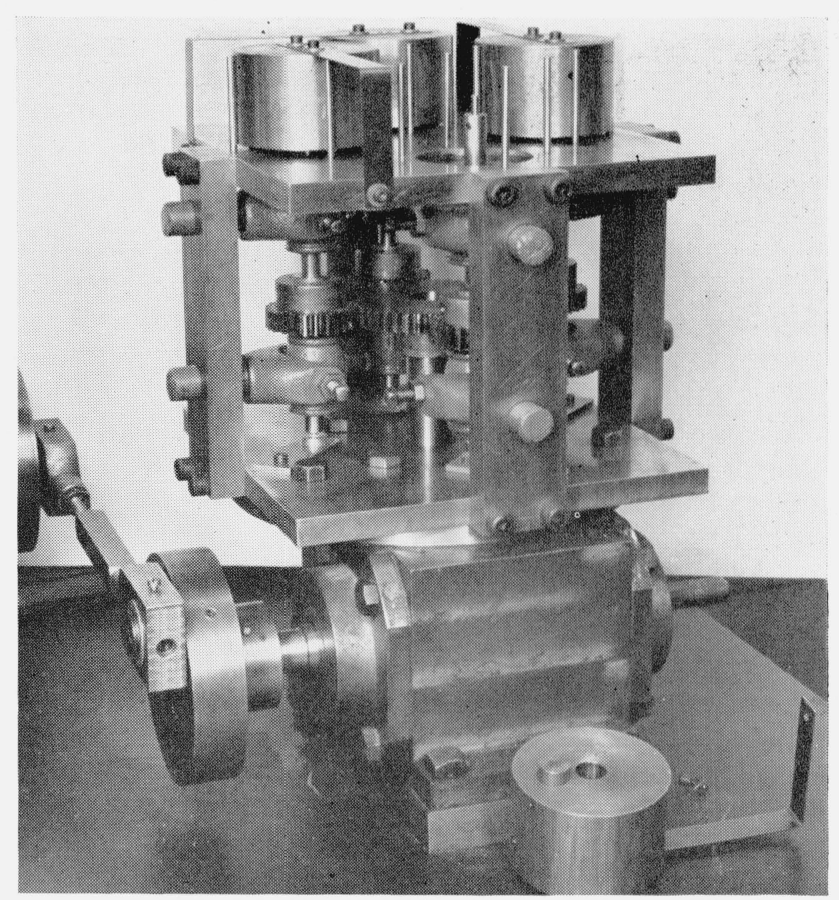

FIGURE 3. Thrust-bearing (endstone) wear-testing machine. 


\subsection{Timepieces}

The timepieces used in a study of the suitability of the more promising bearing materials included aircraft clocks, ship clocks, navigation watches (type AN5740), ship chronometers, low-priced pocket watches (no jewels), and automobile electric clocks. Low-temperature tests of the timepieces were made in a commercial subzero chest in which thermostatically controlled temperatures down to $-60^{\circ} \mathrm{C}$ were maintained.

\section{Test Procedures}

\subsection{Static-Friction Tests}

The coefficient of static friction between two solids depends largely on the physical and chemical properties of the surfaces [4]. Such factors as different surface finishes and the presence of surface films of oxides, oil, or dirt can seriously affect the reproducibility of friction data during a test program. As these factors vary in practice also, it was believed that in this project no purpose would be served by attempting to approach perfectly smooth and chemically clean surfaces. Instead, it seemed best to try to maintain a certain consistency in these variables, with a reasonable degree of cleanliness.

Accordingly, the surfaces for the static-friction tests were initially washed with soap and water, acetone, and ethyl alcohol; and thereafter, at frequent intervals between tests, wiped with industrial absorbent tissue soaked in ethyl alcohol. As far as possible, the original surface finishes of the specimens were left untouched throughout the tests, but there were a few exceptions, where refinishing was thought advisable.

For a particular set of conditions a friction measurement was taken by placing the rider on the plate and in contact with the needle, applying the load, retracting the needle about 0.004 in., and tilting the plate slowly until the signal lamp lit. This was repeated until a relatively constant value was obtained. Plate temperatures were measured by a thermocouple, and atmospheric temperatures inside the temperature-control box were determined with a liquid-in-glass thermometer.

\subsection{Bearing-Friction Tests}

Most of the important comparative friction data were obtained with the small outboard-test-bearing machine that was used in the temperature-control box. In general, the test bearings, 0.50 in. long, with bores slightly less than $1 / 4$ in., were pressed in a steel housing with a 0.500 -in. bore, and then the bearing bore was reamed, burnished, or otherwise smoothly finished to the desired diameter. In these tests, benzene and tissue were used to clean the shafts and bearings, except that no solvent was used on the sintered nylon bearings. To minimize changes of the bearing surface during a test covering a range of temperature, the shaft was not rotated continuously but only for short periods before and while obtaining friction measurements. The air-circulating blower was stopped while the torque was being read, so that the pendulum would not be influenced by the air currents. Observations of the torque were taken at intervals as the temperature near the bearing was reduced from room temperature to $-70^{\circ} \mathrm{C}$, and as the temperature was increased from room temperature to $+70^{\circ} \mathrm{C}$, unless excessively high friction resulted before reaching these temperatures. A damping fluid was used around the lower end of the pendulum rod to minimize fluctuations.

In general, the test shafts were ground, honed, or lapped, and polished with $4 / 0$ polishing paper to give a surface finish in the range of 1 to $3 \mu \mathrm{in}$.

\subsection{Bearing-Storage Tests}

For the storage test, three steel shafts, $1 / 4$ in. in diameter by $7 \frac{1}{2}$ in. long, were supported at the ends, above and parallel to a steel plate, $5 \mathrm{in}$. by $7 \frac{1}{2} \mathrm{in}$. Test bearings, $1 / 2$-in outside diameter by $1 / 2$ in. long, were mounted in steel housings weighing $100 \mathrm{~g}$ each, and were reamed so that each bearing had a diametral clearance of 0.010 in. Brass collars with setscrews were used to space six bearings on each shaft so that each bearing had $1 / 8$ in. side play for axial movement. The shaft ends were clamped to the supports projecting upward from each end of the steel plate.

In making friction measurements for the beginning of the storage test, the above assembly was mounted on the static friction machine. The plate was tilted backward until all the bearings were touching the brass spacing collars, and then tilted forward until the pointer reading for the tangent of the angle was 0.05 . Thereafter, the table was tilted to increase the reading 0.01 at the end of each minute, and a record was made for any bearing that moved axially during each increase in the angle of tilt. During the storage period the assembly was stored on a wooden shelf attached to a brick wall, with the plate tilted about 8 deg to insure that each bearing remained in contact with the appropriate brass spacing collar. The assembly was open to the room air but was protected overhead by another shelf and directly in front by a clear plastic shield, to safeguard against disturbance by falling plaster or wind-blown objects. After 10 months of storage the assembly was mounted on the static-friction machine again to determine the coefficient of starting friction after storage.

\subsection{Bearing-Wear Tests}

The modified multiple-shaft speed-reducing units were used to obtain the rates of wear with bearings on 1/4-in.-diameter journals that were rotated at various speeds, except that for the 1,800-rpm tests the journal was fitted directly to the shaft of an electric motor. The surface finish of the journals at the start of each test was from 1 to $4 \mu$ in., except for some special tests with rougher finishes up to $16 \mu \mathrm{in}$. The bearings were cleaned, weighed, and pressed in steel housings from which suitable loads were suspended. If rapid wear was evidenced by particles of the bearing material accumulating under 
the bearing within a few hours, the bearing was removed and weighed to determine the loss in weight. If no particles from wear were observed beneath the bearing, operation was continued several hundred hours before examination and weighing.

Wear data were obtained from typical oil-free materials on the $1 / 8$-in. oscillating shafts of the modified oscillating display motors. The total angle of motion was about 1 radian $\left(55^{\circ}\right.$ to $\left.60^{\circ}\right)$, with about $3 \mathrm{cps}$, corresponding approximately to simple harmonic motion with an amplitude of 0.5 radian. In each test, a pair of bearings, each 0.25 -in. outside diameter by 0.125 in. long with 0.126 -in. bore, was fitted to the brass yoke previously described (see fig. 2). The bearings were weighed before and after 60 days of operation. The surface finish of the journals at the start of each test was about $2 \mu \mathrm{in}$.

Wear data were obtained with samples of typical materials on the endstone-wear testing machine shown in figure 3 . The test pins were $1 / 8 \mathrm{in}$. in diameter, with $1 / 8$-in. radius at the ends. Tolerance on the radius was \pm 0.001 in., with a surface finish of about $2 \mu$ in. The total angle of motion was about 3 radians $\left(172^{\circ}\right.$ to $\left.175^{\circ}\right)$, with 1 cps, corresponding approximately to simple harmonic motion with an amplitude of 1.5 radians. A dial indicator having a ball point with a radius of about $1 / 16$ in. was mounted over a flat-surface plate and used to measure the depth of wear periodically. When the depth of wear was relatively small, the diameter of the worn spot was measured also with a microscope.

\subsection{Timepiece-Bearing Tests}

Most of the operation with timepieces was at room temperature (about $25^{\circ} \mathrm{C}$ ). A laboratory oven with a thermostat was used for maintaining the high temperature $\left(75^{\circ} \mathrm{C}\right)$, and the subzero chest was used for the low-temperature (mostly $-60^{\circ} \mathrm{C}$ ) tests of timepiece operation. The daily rates were determined by comparison with standard NBS time signals available in the laboratory.

At suitable intervals, the oil-free bearings and shafts in the timepieces were examined for evidences of wear and corrosion. Conventional stereomicroscopes and measuring microscopes (10 to $100 x)$ were used for these examinations.

\section{Results}

\subsection{Static-Friction Results}

Some preliminary testing was done in order to study reproducibility and the effect of load variation. For the range of pressures from about 10 to 30 psi, the starting friction was practically independent of load, for the materials investigated. A constant load that gave a pressure of 17 psi on the loaded area was used for the subsequent static-friction experiments.

As the cooling of the temperature-control box normally was accomplished by the evaporation of dry ice, the atmosphere inside the box during the

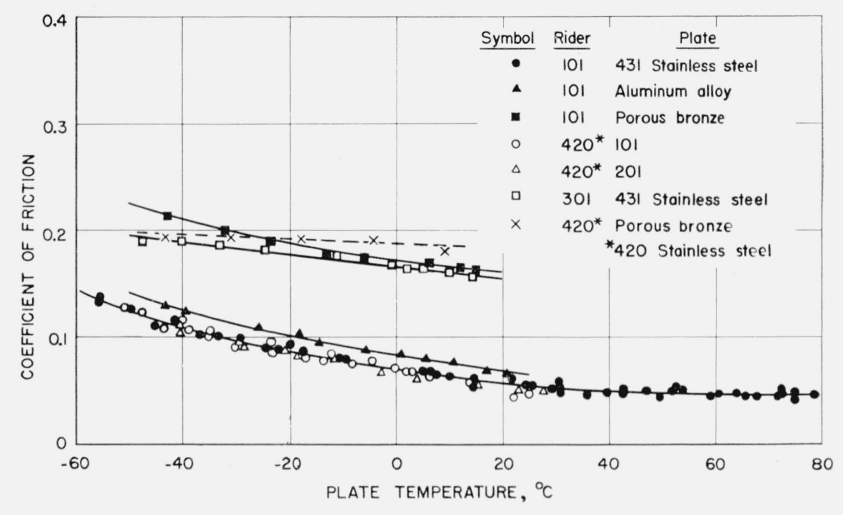

Figure 4. Effect of temperature on the coefficient of static friction.

low-temperature tests was composed mostly of gaseous carbon dioxide. In order to determine whether or not this influenced the results, some tests were run with a different cooling system. Alcohol was cooled externally by dry ice, and pumped through heat-exchanger elements over which the air in the box was circulated. Although this particular system did not cool the box below $-25^{\circ} \mathrm{C}$, the results obtained in this range with atmospheric air coincided very well with those from other tests conducted in the carbon dioxide atmosphere.

The effect of temperature on the static or starting friction for several combinations of different materials is shown in figure 4 . The combinations that include PTFE (sample 101) or PTFE with fillers (sample 201) demonstrate an increase in friction with a decrease in temperature. For PTFE sliding on a 431 stainless-steel plate, and for 420 stainless steel sliding on PTFE and on plate 201 (PTFE + filler), the static friction versus temperature is represented by the lower curve in figure 4; the curve for PTFE sliding on aluminum is slightly higher. For PTFE sliding on dry porous bronze, and for porous bronze impregnated with PTFE (sample 301) sliding on stainless steel, the friction is much higher and is approximately the same as for stainless steel sliding on dry porous bronze. The porous bronze impregnated with PTFE did not have a film of PTFE over its surface, and evidently there was metal-to-metal contact between the bronze and the steel. With a coating of P'TFE on the porous bronze, friction data (not shown in fig. 4) was similar to that for solid PTFE.

\subsection{Bearing-Friction Results}

\section{a. Lubricated Bearings}

For reference purposes, the coefficients of friction at speeds from 3 to $600 \mathrm{rpm}$. were determined with a sapphire (not oriented) bearing ( $1 / 2$ in. long) on a hardened 420 stainless-steel shaft, at $25^{\circ} \mathrm{C}$, with a $643-\mathrm{g}$ load. The diameter of the bore at the largest end was $0.2542 \mathrm{in}$. and at the smallest part of the bore near the center was $0.2524 \mathrm{in}$. The results of these tests are shown in figure 5. As would be 


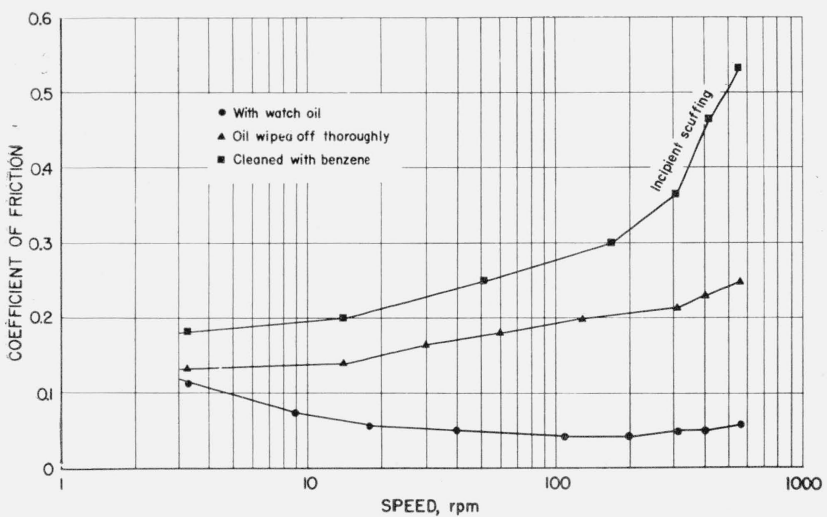

FIGURE 5. Friction versus speed for a polished sapphire bearing.

expected, when fully lubricated with a modern synthetic watch oil, at speeds above $15 \mathrm{rpm}(1.0 \mathrm{fpm})$ the friction was relatively low. When the speed was decreased to about $3 \mathrm{rpm}(0.2 \mathrm{fpm})$, evidently operation was in the thin-film region of lubrication, as there was little difference in friction with abundant oil supply and with a trace of oil left after wiping the shaft and bearing thoroughly with industrial absorbent paper. At higher speeds the inadequate oil supply resulted in higher friction. Removing the traces of oil by washing with benzene resulted in higher friction and incipient scuffing at the bigher speeds; the score marks on the journal and the bearing bore were detected with a 20-power stereomicroscope after removing a brown deposit.

In general, when the lubricated jewels in a timepiece were replaced with oil-free bearings, the mainspring, metal bearings, and winding mechanism were lubricated with a low-temperature lubricant. Because of this, and for general information, friction data were obtained with a hardened 420 stainlesssteel bearing on a hardened 420 stainless-steel shaft when lubricated with three low-temperature oils. These data, for a $2,200-\mathrm{g}$ load, at 3 speeds, and for a range from $-70^{\circ}$ to $+60^{\circ} \mathrm{C}$, are given in table 3 . The surface speed at $3 \mathrm{rpm}$ with the 1/4-in.-diameter shaft more nearly simulates the surface speeds in timepieces; and, at this speed, the coefficient of

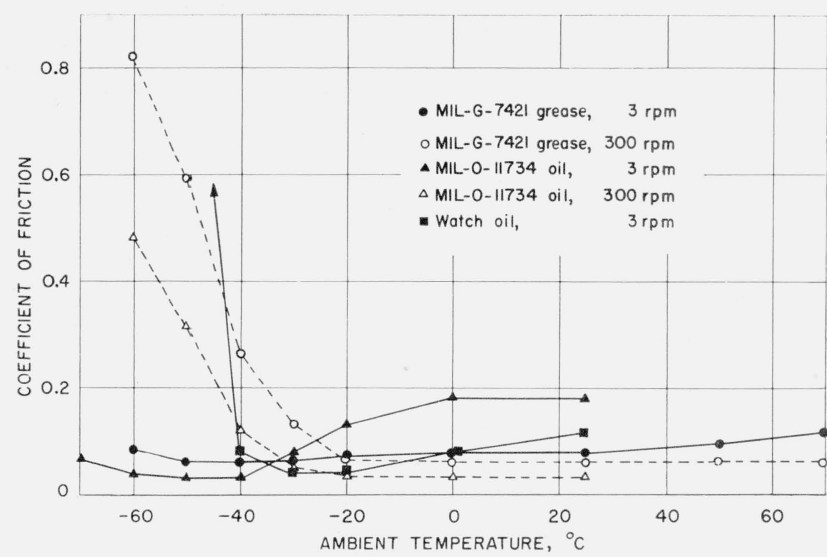

Figure 6. Friction versus temperature for a stainless-steel. bearing.

friction decreases when the temperature is lowered sufficiently for the increasing viscosity to provide a thicker film of oil for lubrication. The relatively high firction at the higher temperatures indicates operation in the thin-film or boundary region of lubrication, in which oiliness is an important factor; and the lwoer friction with the special silicone fluid under these conditions indicates that it has greater oiliness than that of the other two synthetic oils. The MIL-O-11734 [5] and the MIL-L-17353 [6] lubricants are diester-type synthetic oils containing rustinhibitor additives, designed for use in mechanical time fuzes and firearm mechanisms respectively. These two oils are not of the nonspreading type, such as watch oils, commonly used for jewel bearings; however, they do not have the extreme spreading tendency common to silicone fluids.

With the 420 stainless-steel bearing and shaft, with a $643-\mathrm{g}$ load, friction data were obtained over a wide range of ambient temperature with MIL-O11734 oil and MII-G-7421 (extreme low temperature) [7] grease at 3 and $300 \mathrm{rpm}$, and with watch oil at $3 \mathrm{rpm}$. These data are given in figure 6 . The relatively high friction with MIL-O-11734 oil at 3 $\mathrm{rpm}$ at temperatures above $-30^{\circ} \mathrm{C}$ indicates that this operation is in the thin-film or boundary region,

TABLE 3. Friction versus temperature for a honed-and-polished hardened 420 stainless-steel bearing, 0.2520-in. bore, cylindrical; with a hardened 420 stainless-steel shaft, 0.2504-in. diameter, with 2,200-g load; lubricated; at three speeds

\begin{tabular}{|c|c|c|c|c|c|c|c|c|c|}
\hline \multirow{3}{*}{$\begin{array}{l}\text { Ambient } \\
\text { temper- } \\
\text { ature }\end{array}$} & \multicolumn{9}{|c|}{ Coefficient of friction } \\
\hline & \multicolumn{3}{|c|}{ MIL-O-11734 oil } & \multicolumn{3}{|c|}{ MIL-L-17353 oil } & \multicolumn{3}{|c|}{ Silicone fluid } \\
\hline & $3 \mathrm{rpm}$ & $15 \mathrm{rpm}$ & $300 \mathrm{rpm}$ & $3 \mathrm{rpm}$ & $15 \mathrm{rpm}$ & $300 \mathrm{rpm}$ & $3 \mathrm{rpm}$ & $15 \mathrm{rpm}$ & $300 \mathrm{rpm}$ \\
\hline${ }^{\circ} \mathrm{C}$ & & & & & & & & & \\
\hline 60 & 0.19 & 0.16 & 0.01 & 0.22 & 0.20 & 0.03 & 0.13 & 0.11 & $<0.01$ \\
\hline 40 & .18 & .15 & $<.01$ & .22 & .20 & .01 & .10 & .09 & $<.01$ \\
\hline 25 & .18 & .15 & $<.01$ & .20 & .20 & $<.01$ & .10 & .09 & $<.01$ \\
\hline 0 & .18 & .15 & $<.01$ & .20 & .18 & $<.01$ & .10 & .09 & $<.01$ \\
\hline-20 & & .17 & $<.01$ & .18 & .15 & $<.01$ & .10 & .05 & $<.01$ \\
\hline-40 & & $<.01$ & .01 & .15 & .08 & $<.01$ & $\begin{array}{l}.09 \\
.09\end{array}$ & .01 & .01 \\
\hline-50 & $<.01$ & .01 & .06 & & $<.01$ & $<.01$ & .05 & $<.01$ & .02 \\
\hline-60 & $<.01$ & .03 & .27 & $<.01$ & $<.01$ & .04 & $<.01$ & $<.01$ & .04 \\
\hline-70 & & & $-\ldots$ & $<.01$ & .01 & .09 & & & \\
\hline
\end{tabular}


and the addition of an oiliness agent would be expected to lower the friction under these conditions.

In these and other friction tests, the surface finish of the shafts was kept in the range of 1 to $3 \mu \mathrm{in}$. as measured by a profilometer.

\section{b. Oil-Free Bearings}

The effects of temperature on kinetic friction for different clearances with various materials were investigated with the small outboard-test-bearing machine with hardened stainless-steel shafts ranging in diameter from $0.2496 \mathrm{in}$. to $0.2520 \mathrm{in}$. These tests were run in the temperature-control box, at $300 \mathrm{rpm}$, with a $643-\mathrm{g}$ load. These data from PTFE are given in figure 7 . With a diametral clearance of 0.0024 in., the friction was nearly constant from $-65^{\circ}$ to $+70^{\circ} \mathrm{C}$. With a clearance of 0.0016 in. (at room temperature), the friction increased rapidly at about $-50^{\circ} \mathrm{C}$ and at about $+50^{\circ} \mathrm{C}$, because of binding as the clearance decreased to zero. For the clearances investigated, the friction at $300 \mathrm{rpm}$ was practically independent of clearance, and not greatly affected by temperature, except when binding occurred as a result of dimensional changes caused by the changes in temperature. The coefficient of expansion of P'TFE is about 10 times greater than that of steel. At elevated temperatures, the restraint of the steel housing in preventing outward expansion of the plastic causes the bore to become smaller instead of larger. Conversely, as the temperature is lowered, release of the press fit tends to counterbalance the contraction of the bore of the plastic until the temperature is low enough for the bearing to become loose in the steel bore. To prevent movement of the plastic and the filled-plastic types of bearing in the steel housing at low temperatures, a small floating pin was inserted radially through the bearing housing into a matching hole extending $1 / 16$ in. into the bearing wall.

Typical data showing the effect of speed on friction for several materials are given in figure 8 . These data were obtained at $25^{\circ} \mathrm{C}$ with a $643-\mathrm{g}$ load, using a stainless-steel shaft having a 0.2504-in. diameter.

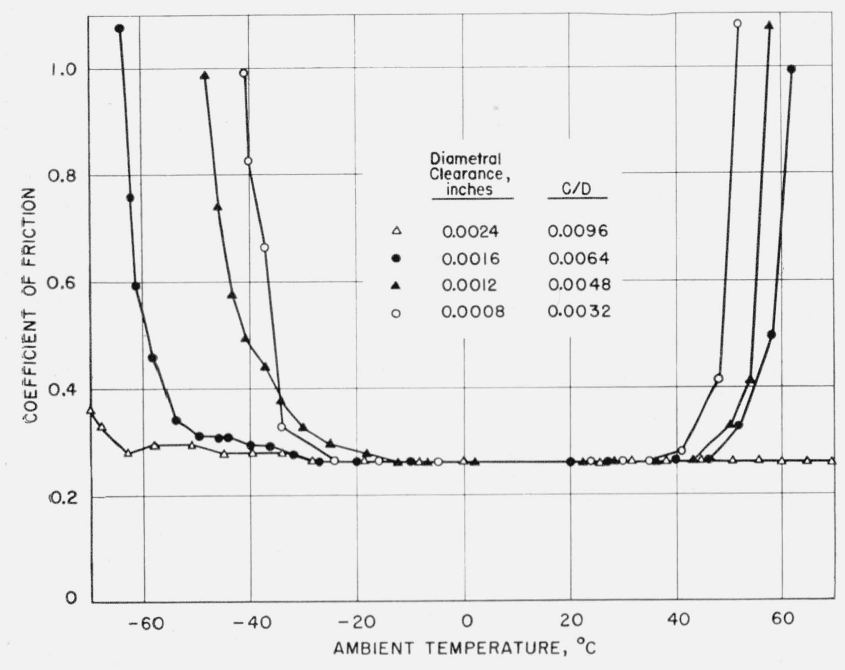

FIGURE 7. Friction versus temperature for a PTFE bearing, at $300 \mathrm{rpm}$, with various clearances at room temperature.
The test of the lapped-and-polished Pyrex-glass bearing lubricated with watch oil was made to obtain comparable data on a hard lubricated material similar to jewels (before the sapphire bearing was obtained). At $15 \mathrm{rpm}$, where the surface speed is about the maximum encountered in a timepiece bearing, the friction for PTFE is about 60 percent greater than with the lubricated glass, but at $2.5 \mathrm{rpm}$ the friction of this plastic is the same as that of the lubricated glass.

The coefficients of friction at $25^{\circ} \mathrm{C}$, using a $643-\mathrm{g}$ load with $1 / 4-$ in.-diameter stainless-steel shafts at 3 , 15 , and $300 \mathrm{rpm}$, for many oil-free materials and for typical lubricated bearings, are given in table 4 .

After it became evident that loads greater than $643 \mathrm{~g}$ could be tolerated (without excessive wear) with the $1 / 4$-in.-bore oil-free bearings, friction data were obtained with a $2,200-\mathrm{g}$ load, and these data are considered more important than the data obtained with the $643-\mathrm{g}$ load. In these tests with the heavier load, friction data were obtained at speeds ranging from 2 to $600 \mathrm{rpm}$, and then the bearing was run in at $300 \mathrm{rpm}$ to observe changes in friction. Friction data were obtained over the speed range after various amounts of run-in at $300 \mathrm{rpm}$, to investigate the effect of run-in at the relatively high load and speed. Typical data for these tests with samples 101 and 215 are given in figure 9, which also includes data (dotted curve) for a lubricated stainless steel bearing for comparative purposes. Because of excessive wear with sample 101 (PTFE) under these conditions, run-in with this material was limited to $1 \mathrm{hr}$ and no data were obtained above

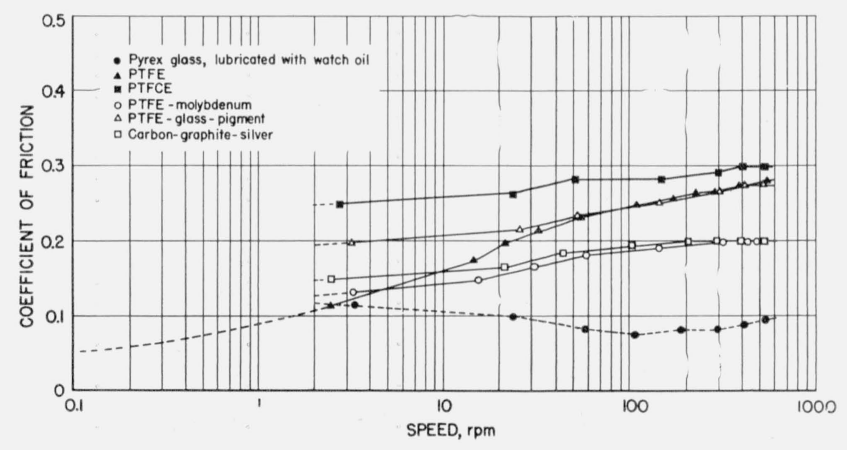

Figure 8. Friction versus speed for various bearing materials, with 643-g load.

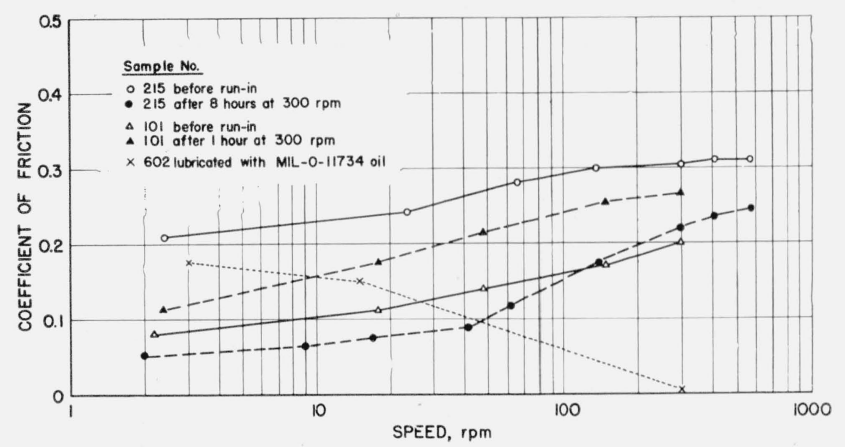

FIGURE 9. Friction versus speed for typical bearing materials, with 2,200-g loxd. 
TABLE 4. Coefficient of friction for various bearing materials, with hardened 420 stainless-steel shafts, 1/4-in. diameter, at room temperature, with 643-g load

\begin{tabular}{|c|c|c|c|}
\hline \multirow{2}{*}{ Sample } & \multicolumn{3}{|c|}{ Coefficient of friction } \\
\hline & $3 \underset{\mathrm{fpm})}{\mathrm{rpm}(0.2}$ & $15 \underset{\mathrm{fpm})}{\mathrm{rpm}}(1.0$ & $\begin{array}{c}300 \mathrm{rpm} \\
\mathrm{fpm})\end{array}$ \\
\hline $\begin{array}{l}101 \\
102 \\
103 \\
103 \mathrm{a}\end{array}$ & $\begin{array}{c}0.12 \\
.25 \text { to } .27 \\
.22 \\
.28\end{array}$ & $\begin{array}{c}0.18 \\
.26 \text { to } .28 \\
.20 \\
.26\end{array}$ & $\begin{array}{l} \\
0.26 \\
.29 \text { to } .45 \\
.28 \text { to } .35 \\
.28 \text { to } .32 \\
.32 \text { to. } 33\end{array}$ \\
\hline $\begin{array}{l}201 \\
202 \\
202 \mathrm{a} \\
202 \mathrm{~b} \\
202 \mathrm{c}\end{array}$ & $\begin{array}{l}.20 \\
.13 \\
.20 \\
.20 \\
.20\end{array}$ & $\begin{array}{l}.21 \\
.15 \\
.21 \\
.21 \\
.21\end{array}$ & $\begin{array}{l}.26 \text { to } .32 \\
.20 \\
.23 \\
.23 \\
.23\end{array}$ \\
\hline $\begin{array}{l}203 \ldots \\
204 \ldots \\
204 \mathrm{a} \\
205 \\
206 \\
-\end{array}$ & $\begin{array}{l}.27 \\
.13 \\
.13 \\
.13\end{array}$ & $\begin{array}{l}.26 \\
.15 \\
.16 \\
.18\end{array}$ & $\begin{array}{l}.23 \\
.28 \\
.21 \\
.22 \\
.28\end{array}$ \\
\hline $\begin{array}{l}206 \mathrm{a} \\
207 \\
208 \\
208 \mathrm{a} \\
209 \\
-\end{array}$ & $\begin{array}{l}.26 \\
.16 \text { to. } 25 \\
.18 \\
.26 \\
.11\end{array}$ & $\begin{array}{l}.18 \text { to } .26 \\
.20 \\
.26 \\
.13\end{array}$ & $\begin{array}{l}.31 \\
.24 \text { to } .29 \\
.22 \\
.28 \\
.18\end{array}$ \\
\hline $\begin{array}{l}210 \ldots \\
211 \ldots \\
212 \ldots \\
213 \\
214 \ldots\end{array}$ & $\begin{array}{l}.11 \\
.15 \\
.16 \\
.36 \\
.16\end{array}$ & $\begin{array}{l}.14 \\
.19 \\
.18 \\
.36 \\
.19\end{array}$ & $\begin{array}{l}.17 \\
.26 \\
.23 \\
.40 \\
.23\end{array}$ \\
\hline $\begin{array}{l}215 \\
215 \mathrm{a} \\
216 \\
217 \\
218\end{array}$ & $\begin{array}{l}.22 \\
.28 \\
.13 \\
.23 \\
.26\end{array}$ & $\begin{array}{l}.22 \\
.26 \\
.15 \\
.23 \\
.26\end{array}$ & $\begin{array}{l}.26 \\
.23 \\
.19 \\
.27 \\
.26\end{array}$ \\
\hline $\begin{array}{l}218 \mathrm{a} \\
219 \\
220 \\
220 \mathrm{a} \\
221\end{array}$ & $\begin{array}{l}.26 \\
.20 \\
.30 \\
.23 \\
.15\end{array}$ & $\begin{array}{l}.26 \\
.22 \\
.31 \\
.25 \\
.16\end{array}$ & $\begin{array}{l}.27 \\
.25 \\
.33 \\
.30 \\
.19\end{array}$ \\
\hline $\begin{array}{l}222 \\
223 . \\
224 \ldots \\
225 \ldots \\
226\end{array}$ & $\begin{array}{l}.12 \\
.18 \\
.13 \\
.17 \\
.13\end{array}$ & $\begin{array}{l}.13 \\
.19 \\
.15 \\
.18 \\
.16\end{array}$ & $\begin{array}{l}.17 \\
.22 \\
.20 \\
.22 \\
.25\end{array}$ \\
\hline $\begin{array}{l}227 \mathrm{a}_{-} \\
228 \\
229\end{array}$ & $\begin{array}{l}.15 \\
.22 \\
.22\end{array}$ & $\begin{array}{l}.17 \\
.23 \\
.23\end{array}$ & $\begin{array}{l}.20 \\
.25 \\
.25\end{array}$ \\
\hline $\begin{array}{l}401 \\
402 \\
403 \\
404\end{array}$ & $\begin{array}{l}.15 \\
.28 \\
.21 \\
.27\end{array}$ & $\begin{array}{l}.16 \\
.28 \\
.22 \\
.27\end{array}$ & $\begin{array}{c}.20 \text { to } .28 \\
.27 \\
.23 \\
.26\end{array}$ \\
\hline $501 \ldots$ & .13 & .13 & .12 \\
\hline 602 with MIL-G-7421 grease & .08 & .06 & .06 \\
\hline 602 with MIL-O-11734 oil ... & .18 & .16 & .03 \\
\hline $\begin{array}{l}602 \text { with watch oil } \\
603 \text { with watch oil } \\
604 \text { with watch oil } \\
604 \text { oil wiped off } \\
604 \text { clean }\end{array}$ & $\begin{array}{l}.12 \\
.13 \\
.12 \\
.13 \\
.18\end{array}$ & $\begin{array}{l}.06 \\
.06 \\
.06 \\
.14 \\
.20\end{array}$ & $\begin{array}{l}.04 \\
.05 \\
.05 \\
.21 \\
.36\end{array}$ \\
\hline
\end{tabular}

$300 \mathrm{rpm}$. Even so, rapid wear occurred and the friction increased about 50 percent during the run-in with this bearing. Before run-in, the friction with sample 215 was much higher than with sample 101; but after run-in, the friction with sample 215 was lower than with sample 101.

Friction data obtained with a hardened stain!esssteel shaft at 3,15 , and $300 \mathrm{rpm}$, showing the effect of run-in and the effect of ambient temperature on friction, are given in table 5 . With respect to timepieces the coefficient of friction at $3 \mathrm{rpm}(0.2 \mathrm{fpm})$ is considered more significant than the data at higher speeds. Also, the friction after run-in is considered more significant than the initial friction.

For the four samples of PTFE-molybdenum metal powder (samples 202c, 238, 238a, and 238b), after several hours of operation at $300 \mathrm{rpm}$ and then at $3 \mathrm{rpm}$, at $25^{\circ} \mathrm{C}$, the coefficient of friction was in the range 0.18 to 0.26 . After continued running at $3 \mathrm{rpm}$ at $-60^{\circ} \mathrm{C}$ the coefficient of friction at $-60^{\circ} \mathrm{C}$ was 0.22 to 0.25 . The concentration of molybdenum in these samples ranges from 50 to 75 percent (20 to 42 volume percent); for this range of concentration the coefficient of friction at $3 \mathrm{rpm}$ was not greatly affected by temperature variations in this range from $+25^{\circ} \mathrm{C}$ to $-60^{\circ} \mathrm{C}$. Likewise, the friction for sample 401 (carbon+graphite+silver) was not greatly affected by temperature.

For the high-density polyethylene (sample 104) and with unlubricated sapphire there was an increase in friction as the temperature was decreased below $-20^{\circ} \mathrm{C}$.

For the commercial bearing of sintered bronze+ molybdenum disulfide (sample 304) the coefficient of friction increased from 0.17 to 0.44 during 12 min of operation at $3 \mathrm{rpm}$ with the $2,200-\mathrm{g}$ load. After turning the bearing $180^{\circ}$ in its holder, in another test (not included in the table) with a $643-\mathrm{g}$ load the coefficient of friction increased from 0.17 to 0.60 during $1 \mathrm{hr}$ of operation at $3 \mathrm{rpm}$.

For the sample of bearing bronze (sample 605) the coefficient of friction increased from 0.13 to 0.44 during an hour of operation at $3 \mathrm{rpm}$ with the $2,200 \mathrm{-g}$ load. After turning this bearing $180^{\circ}$, with a $643-\mathrm{g}$ load, the coefficient of friction increased from 0.15 to 0.55 during $2 \mathrm{hr}$ of operation at $3 \mathrm{rpm}$.

For the sample of commercial coating (sample 606), consisting of tungsten and molybdenum disulfide in a plastic, the coefficient of friction increased from 0.29 to 0.52 during an hour of operation at 3 rpm with a $2,200-\mathrm{g}$ load.

It is of interest to note that under the conditions of these tests, the ordinary bearing bronze $(83 \%$ copper, $8 \%$ tin, $8 \%$ lead) was somewhat superior to the bronze containing molybdenum disulfide and also to the commercial plastic coating material containing tungsten and molybdenum disulfide; but each of these samples was inferior to most of the other materials.

For sample 609 (graphite added to P'TFCE) the friction was relatively high; above $-20^{\circ} \mathrm{C}$ it was similar to the friction for P'TFCE, and at lower temperatures the friction was greater than that of P'TFCE.

For PTFCE bearings (at $3 \mathrm{rpm}$ ) the friction decreased with a decrease in temperature; but with P'TFE or P'TFCE containing P'TFE as a filler the friction increased with a decrease in temperature in the temperature range from $-20^{\circ}$ to $-60^{\circ} \mathrm{C}$. This is illustrated in figure 10, with data for PTFCE, P'TFE, and samples of P'TFCE resin containing P'TFE filler. 
Data obtained in England [8], with the apparatus and method of test greatly different from that used at NBS, show no change in friction for PTFE in the range from $-55^{\circ}$ to $-80^{\circ} \mathrm{C}$. At temperatures down to $-55^{\circ} \mathrm{C}$ the data are in general agreement with the data obtained at $3 \mathrm{rpm}$ at NBS.

Figure 10. Friction versus temperature for PTFE, PTFCE, and PTFCE plus PTFE bearings.

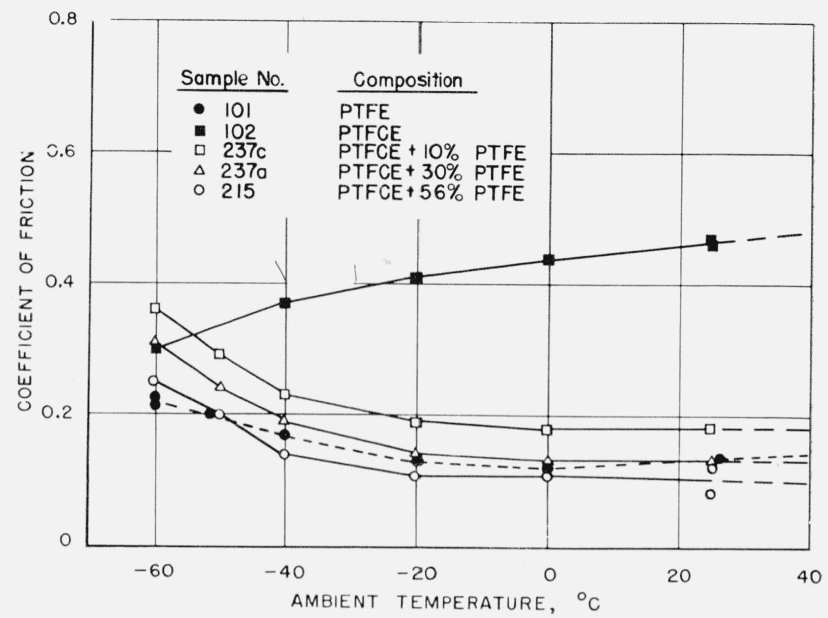

TABLE 5. Effect of run-in and effect of temperature on the coefficient of friction for various bearing materials, with a hardened 420 stainless-steel shaft, 1/4-in. diameter

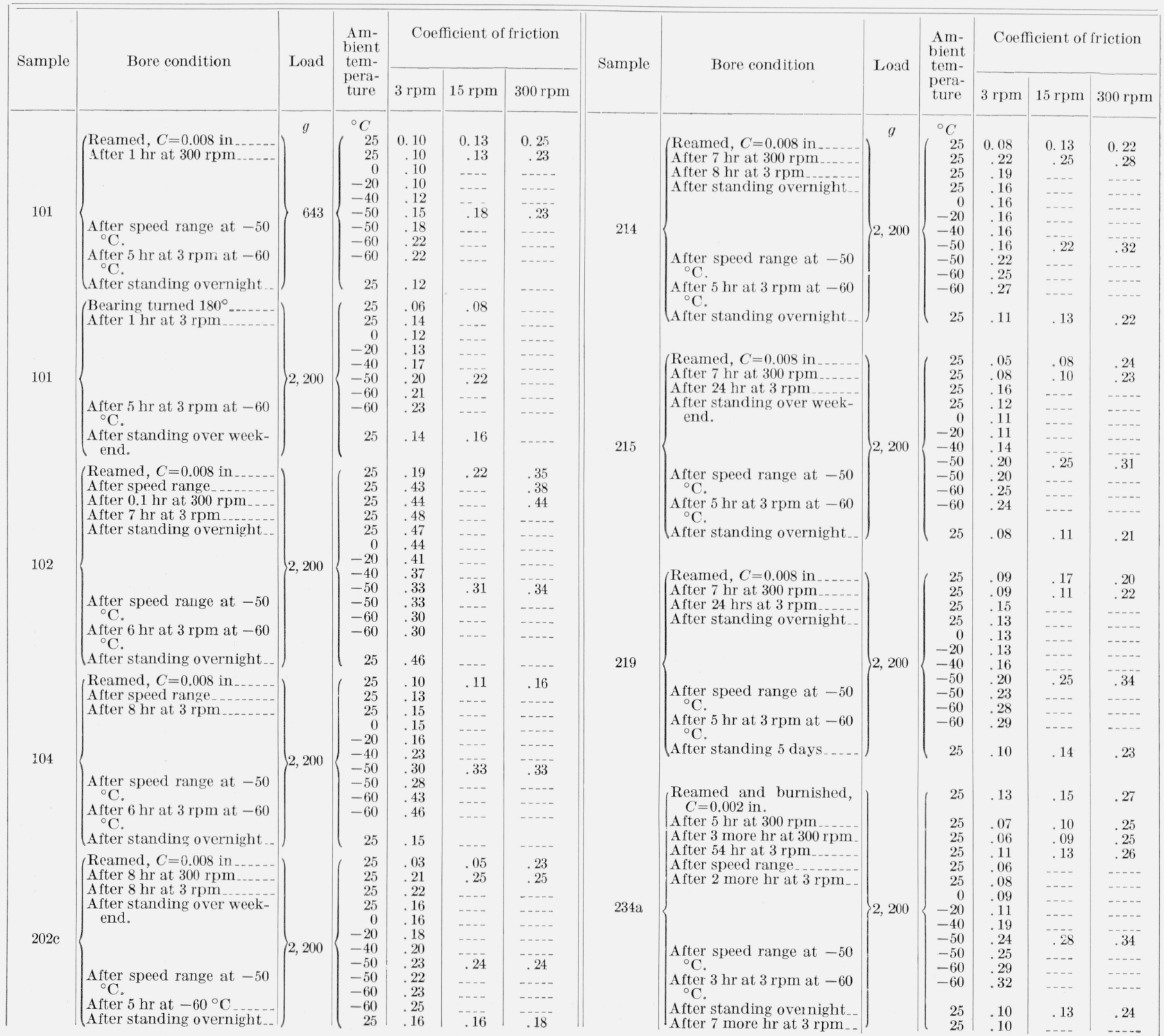


TABLE 5. Effect of run-in and effect of temperature on the coefficient of friction for various bearing materials, with' $a$ hardened 420 stainless-steel shaft, 1/4-in. diameter-Continued

\begin{tabular}{|c|c|c|c|c|c|c|c|c|c|c|c|c|c|}
\hline \multirow{2}{*}{ Sample } & \multirow{2}{*}{ Bore condition } & \multirow{2}{*}{ Load } & \multirow{2}{*}{$\begin{array}{c}\text { Am- } \\
\text { bient } \\
\text { tem- } \\
\text { pera- } \\
\text { ture }\end{array}$} & \multicolumn{3}{|c|}{ Coefficient of friction } & \multirow{2}{*}{ Sample } & \multirow{2}{*}{ Bore condition } & \multirow{2}{*}{ Load } & \multirow{2}{*}{$\begin{array}{c}\text { Am- } \\
\text { bient } \\
\text { tem- } \\
\text { pera- } \\
\text { ture }\end{array}$} & \multicolumn{3}{|c|}{ Coefficient of friction } \\
\hline & & & & $3 \mathrm{rpm}$ & $15 \mathrm{rpm}$ & $300 \mathrm{rpm}$ & & & & & $3 \mathrm{rpm}$ & $15 \mathrm{rpm}$ & $300 \mathrm{rpm}$ \\
\hline 236 & $\left\{\begin{array}{l}\text { Reamed, } C=0.008 \mathrm{in} \\
\text { After } 7 \mathrm{hr} \text { at } 300 \mathrm{rpm} \\
\text { After } 8 \mathrm{hr} \text { at } 3 \mathrm{rpm} \\
\text { After standing overnight.- } \\
\\
\text { After speed range at }-50 \\
{ }^{\circ} \mathrm{C} . \\
\text { After } 5 \mathrm{hr} \text { at } 3 \mathrm{rpm} \text { at }-60 \\
{ }^{\circ} \mathrm{C} .\end{array}\right.$ & 2,200 & $\left\{\begin{array}{r}{ }^{\circ} C \\
25 \\
25 \\
25 \\
25 \\
0 \\
-20 \\
-40 \\
-50 \\
-50 \\
-60 \\
-60 \\
\\
25\end{array}\right.$ & $\begin{array}{r}0.10 \\
.10 \\
.12 \\
.12 \\
.12 \\
.16 \\
.23 \\
.27 \\
.29 \\
.33 \\
.33 \\
.12\end{array}$ & $\begin{array}{r}0.11 \\
.12 \\
-\cdot-- \\
-\cdot- \\
-\cdot- \\
-\cdot- \\
-.30 \\
-\cdots \\
-\cdots \\
-\cdots \\
.15\end{array}$ & 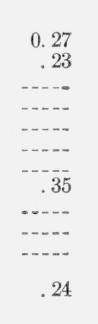 & $238 \mathrm{a}$ & $\left\{\begin{array}{l}\text { Reamed, } C=0.008 \mathrm{in} \\
\text { After } 8 \mathrm{hr} \text { at } 300 \mathrm{rpm} \\
\text { After } 7 \mathrm{hr} \text { at } 3 \mathrm{rpm} \\
\text { After standing over week- } \\
\text { end. } \\
\\
\\
\text { After speed range at }-50^{\circ} \\
\text { C. } \\
\text { After } 6 \mathrm{hr} \text { at } 3 \mathrm{rpm} \text { at }-60^{\circ} \\
\text { C. } \\
\text { After standing overnight.- }\end{array}\right.$ & 2,200 & $\left\{\begin{array}{r}{ }^{\circ} C \\
25 \\
25 \\
25 \\
25 \\
0 \\
-20 \\
-40 \\
-50 \\
-50 \\
-60 \\
-60 \\
25\end{array}\right.$ & $\begin{array}{l}0.06 \\
.29 \\
.25 \\
.21 \\
\\
.22 \\
.22 \\
.23 \\
.25 \\
.23 \\
.25 \\
.25 \\
.18\end{array}$ & 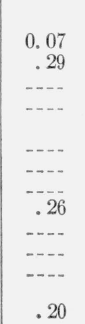 & 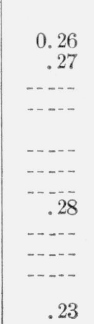 \\
\hline 237 & $\left\{\begin{array}{l}\text { Reamed, } C=0.008 \text { in } \\
\text { After } 6 \text { hr at } 300 \mathrm{rpm} \\
\text { After } 8 \mathrm{hr} \text { at } 3 \mathrm{rpm} \\
\text { After standing } 0 \text { vernight.-- } \\
\\
\text { After speed range at }-50^{\circ} \\
\text { C. } \\
\text { tfter } 6 \text { hr at } 3 \text { rpm at }-60^{\circ} \\
\text { C. } \\
\text { After standing overnight... }\end{array}\right\}$ & 2,200 & $\left\{\begin{array}{r}25 \\
25 \\
25 \\
25 \\
0 \\
-20 \\
-40 \\
-50 \\
-50 \\
-60 \\
-60 \\
\\
25\end{array}\right.$ & $\begin{array}{l}.22 \\
.12 \\
.15 \\
.14 \\
.14 \\
.17 \\
.22 \\
.26 \\
.34 \\
.36 \\
.33 \\
.19\end{array}$ & 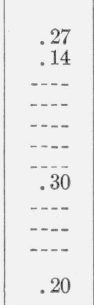 & 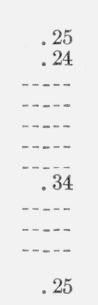 & $238 \mathrm{~b}$ & $\left\{\begin{array}{l}\text { Reamed, } C=0.008 \mathrm{in} \\
\text { After } 8 \mathrm{hr} \text { at } 300 \mathrm{rpm} \\
\text { After } 8 \mathrm{hr} \text { at } 3 \mathrm{rpm} \\
\text { After standing overnight.- } \\
\\
\text { After speed range at }-50^{\circ} \\
\text { C. } \\
\text { After } 6 \mathrm{hr} \text { at } 3 \mathrm{rpm} \text { at }-60^{\circ} \\
\text { C. } \\
\text { After standing overnight.- }\end{array}\right.$ & 2,200 & $\left\{\begin{array}{r}25 \\
25 \\
25 \\
25 \\
0 \\
-20 \\
-40 \\
-50 \\
-50 \\
-60 \\
-60 \\
\\
25\end{array}\right.$ & $\begin{array}{l}.10 \\
.19 \\
.18 \\
.15 \\
.15 \\
.16 \\
.18 \\
.20 \\
.22 \\
.18 \\
.22 \\
.22\end{array}$ & $\begin{array}{l}.15 \\
.21 \\
\cdots-- \\
-\cdots \\
-\cdots \\
.21 \\
-\cdots \\
-\cdots \\
-\cdots \\
.22\end{array}$ & 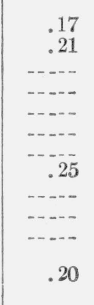 \\
\hline $237 a$ & $\left\{\begin{array}{l}\text { Reamed, C=0.008 in } \\
\text { After } 7 \mathrm{hr} \text { at } 300 \mathrm{rpm} \\
\text { After } 7 \mathrm{hr} \text { at } 3 \mathrm{rpm} \text {-..- } \\
\text { After standing 0vernight.- } \\
\\
\text { After speed range at }-50^{\circ} \\
\text { C. } \\
\text { After } 6 \text { hr at } 3 \mathrm{rpm} \text { at }-60^{\circ} \\
\text { C. } \\
\text { After standing overnight.- }\end{array}\right)$ & 2,200 & $\begin{array}{r}25 \\
25 \\
25 \\
25 \\
0 \\
-20 \\
-40 \\
-50 \\
-50 \\
-60 \\
-60 \\
\\
25\end{array}$ & $\begin{array}{l}.13 \\
.11 \\
.15 \\
.13 \\
.13 \\
.14 \\
.19 \\
.24 \\
.27 \\
.31 \\
.33 \\
.13\end{array}$ & 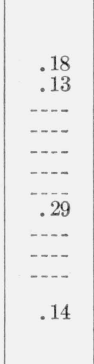 & \begin{tabular}{r}
.23 \\
.24 \\
\hdashline.- \\
-33 \\
.0 \\
.23 \\
-
\end{tabular} & 304 & $\left\{\begin{array}{l}\left\{\begin{array}{l}\text { Reamed, } C=0.0016 \mathrm{in} . \\
\text { After } 0.1 \mathrm{hr} \text { at } 3 \mathrm{rpm} \\
\text { After } 0.2 \mathrm{hr} \text { at } 3 \mathrm{rpm}\end{array}\right. \\
\begin{array}{l}\text { Reamed and burnished, } \\
C=0.002 \mathrm{in} .\end{array} \\
\text { After } 2 \mathrm{hr} \text { at } 300 \mathrm{rpm} \\
\text { After } 4 \text { more hr at } 300 \mathrm{rpm} \text {. }\end{array}\right.$ & 2,200 & $\begin{array}{l}\left\{\begin{array}{r}25 \\
25 \\
25\end{array}\right. \\
\left\{\begin{array}{r}25 \\
25 \\
25 \\
0 \\
-20 \\
-40 \\
-50 \\
-50 \\
-60 \\
-60 \\
25\end{array}\right.\end{array}$ & $\begin{array}{l}.17 \\
.32 \\
.44 \\
.16 \\
.25 \\
.22 \\
.23 \\
.24 \\
.26 \\
.27 \\
.25 \\
.26 \\
.23 \\
.22\end{array}$ & 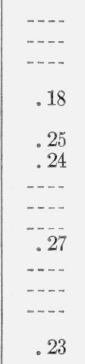 & $\begin{array}{c}-\cdots \\
.23 \\
.27 \\
.27 \\
-\cdots- \\
-\cdots \\
-\cdots \\
.27 \\
-\cdots \\
-\cdots \\
.26\end{array}$ \\
\hline $237 \mathrm{~b}$ & $\left\{\begin{array}{l}\text { After speed range at }-50^{\circ} \\
\text { C. } \\
\text { After } 6 \text { hr at } 3 \text { rpm at }-60^{\circ} \\
\text { C. } \\
\text { After standing overnight_-- }\end{array}\right.$ & 2,200 & $\left\{\begin{array}{r}25 \\
25 \\
25 \\
25 \\
0 \\
-20 \\
-40 \\
-50 \\
-50 \\
-60 \\
-60 \\
\\
25\end{array}\right.$ & $\begin{array}{l}.19 \\
.13 \\
.13 \\
.13 \\
.13 \\
.15 \\
.20 \\
.24 \\
.26 \\
.32 \\
.34 \\
\\
.14\end{array}$ & $\begin{array}{c}.22 \\
.16 \\
-\cdot- \\
-\cdots \\
- \\
.27 \\
-\cdot \\
-\cdot \\
.17\end{array}$ & \begin{tabular}{r}
.30 \\
.25 \\
\hdashline .31 \\
.29 \\
\end{tabular} & 606 & $\left\{\begin{array}{l}\text { Reamed, } C=0.008 \mathrm{in} \\
\text { After } 0.5 \mathrm{hr} \text { at } 3 \mathrm{rpm} \\
\text { After } 1 \mathrm{hr} \text { at } 3 \mathrm{rpm}\end{array}\right.$ & 2,200 & $\begin{array}{r}25 \\
0 \\
-20 \\
-40 \\
-50 \\
-60 \\
\\
25 \\
25 \\
25 \\
\\
25 \\
25 \\
25\end{array}$ & $\begin{array}{l}.18 \\
.19 \\
.20 \\
.23 \\
.26 \\
.28 \\
\\
.13 \\
.29 \\
.44 \\
\\
.29 \\
.50 \\
.52\end{array}$ & $\begin{array}{l}.22 \\
.23 \\
.26 \\
.30 \\
.33 \\
.35 \\
\\
.15 \\
-\cdot- \\
-\cdot \\
- \\
-.- \\
-\cdot-\end{array}$ & 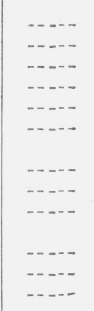 \\
\hline $237 \mathrm{c}$ & $\left(\begin{array}{l}\text { Reamed, } C=0.008 \mathrm{in} \\
\text { After speed run } \\
\text { After } 8 \mathrm{hr} \text { at } 300 \mathrm{rpm} \\
\text { After speed run } \\
\text { After standing over week- } \\
\text { end. } \\
\text { After } 8 \mathrm{hr} \text { at } 3 \mathrm{rpm}\end{array}\right.$ & 2,200 & $\left\{\begin{array}{r}25 \\
25 \\
25 \\
25 \\
25 \\
\\
25 \\
0 \\
-20 \\
-40 \\
-50 \\
-50 \\
-60 \\
-60 \\
\\
25\end{array}\right.$ & $\begin{array}{l}.15 \\
.22 \\
.19 \\
.16 \\
.16 \\
\\
.18 \\
.18 \\
.19 \\
.23 \\
.29 \\
.38 \\
.36 \\
.36 \\
.22\end{array}$ & 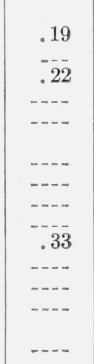 & 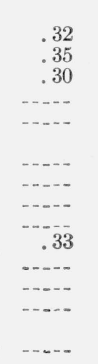 & 609 & $\left\{\begin{array}{l}\text { Coating: thickness }=0.003 \\
\text { in. } C=0.002 \mathrm{in} . \\
\text { After speed run } \\
\text { After } 0.1 \mathrm{hr} \text { at } 300 \mathrm{rpm} \\
\text { After } 8 \mathrm{hr} \text { at } 3 \mathrm{rpm} \\
\text { After standing over holi- } \\
\text { day } \\
\\
\text { After speed range at }-50^{\circ} \\
\mathrm{C} \text {. } \\
\text { After } 6 \text { hr at } 3 \text { rpm at }-60^{\circ} \\
\text { C. } \\
\text { After standing overnight.- }\end{array}\right.$ & 2,200 & $\begin{array}{r}25 \\
25 \\
25 \\
25 \\
\\
25 \\
0 \\
-20 \\
-40 \\
-50 \\
-50 \\
-60 \\
-60 \\
\\
25\end{array}$ & $\begin{array}{l}.41 \\
.44 \\
.38 \\
.41 \\
.41 \\
.41 \\
.41 \\
.41 \\
.41 \\
.41 \\
.42 \\
.48 \\
.48\end{array}$ & 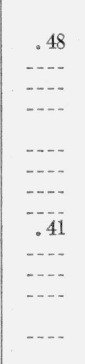 & 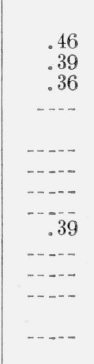 \\
\hline 238 & $\begin{array}{l}\text { After speed range at }-50^{\circ} \\
\text { C. } \\
\text { After } 6 \mathrm{hr} \text { at } 3 \mathrm{rpm} \text { at }-60^{\circ} \\
\text { C. } \\
\text { After standing overnight } . .\end{array}$ & 2,200 & $\left\{\begin{array}{r}25 \\
25 \\
25 \\
25 \\
0 \\
-20 \\
-40 \\
-50 \\
-50 \\
-60 \\
-60 \\
\\
25\end{array}\right.$ & $\begin{array}{l}.08 \\
.21 \\
.26 \\
.18 \\
.18 \\
.18 \\
.20 \\
.21 \\
.22 \\
.22 \\
.23 \\
.19 \\
\end{array}$ & $\begin{array}{r}.13 \\
.23 \\
-\cdot- \\
-. \\
.2 \\
.22 \\
-\cdot- \\
-\cdot- \\
.19 \\
\end{array}$ & $\begin{array}{r}.19 \\
.25 \\
-25 \\
.2 \\
.20 \\
\end{array}$ & 611 & $\begin{array}{l}\text { After speed range at }-50^{\circ} \\
\text { C. } \\
\text { After } 6 \mathrm{hr} \text { at } 3 \mathrm{rpm} \text { at }-60^{\circ} \\
\text { C. } \\
\text { After standing overnight.- }\end{array}$ & 2,200 & $\begin{array}{r}25 \\
25 \\
25 \\
25 \\
25 \\
0 \\
-20 \\
-40 \\
-50 \\
-50 \\
-60 \\
-60 \\
-70 \\
25\end{array}$ & $\begin{array}{l}.03 \\
.11 \\
.13 \\
.15 \\
.13 \\
.13 \\
.13 \\
.15 \\
.18 \\
.19 \\
.20 \\
.18 \\
.18 \\
.13\end{array}$ & $\begin{array}{c}.04 \\
-0 \\
-- \\
-\cdot \\
- \\
. \\
.22 \\
-- \\
- \\
- \\
\end{array}$ & \begin{tabular}{c}
.21 \\
.18 \\
.17 \\
\hdashline.- \\
.24 \\
.-- \\
- \\
- \\
\end{tabular} \\
\hline
\end{tabular}




\section{c. Different Shaft Materials With Oil-Free Bearings}

To investigate the effect of different shaft materials on friction, data were obtained with 4 typical bearing materials on each of 5 different shaft materials, at $25^{\circ} \mathrm{C}$, with a 2,200 -g load, during $8 \mathrm{hr}$ of operation at $3 \mathrm{rpm}$. The data are given in table 6 , in chronological order. With the bearing sample containing molybdenum (sample 202c), after $8 \mathrm{hr}$ of operation the coefficient of friction was 0.07 with the cobalt alloy shaft (C40), 0.15 with the hardened $440 \mathrm{C}$ stainless-steel shaft, 0.33 with the relatively soft machinery steel (sample M), and 0.22 to 0.25 with the two shafts made of hardened high-chromium tool steels (samples D3 and D2). With each of the other three bearing materials, after $8 \mathrm{hr}$ of operation at $3 \mathrm{rpm}$ on each shaft, the friction was not greatly affected by the shaft material.

Check runs given in table 6 for bearings 101 and 215 give some indication of the reproducibility of the friction data under these conditions. However, in initial tests with bearing 101 and these new shafts there was a progressive increase in friction from 0.06 to 0.28 , and a slight brownish glaze was observed on the bearing at its contact area. These test shafts were ground, lapped with diamond dust, and then polished with $4 / 0$ polishing paper. They were cleaned by scrubbing and rinsing with benzene, but it is believed possible that traces of abrasives from the shafts may have been transferred to the bearing. Preliminary operation was continued with occasional cleaning of the bearing with a reamer and with benzene untii a colored glaze no longer formed on the bearing and friction data became reasonably reproducible with check runs.

TABLE 6. Coefficient of friction for typical 1/4-in.-diam bearings, with various steel shafts, with 2,200-g load, at $3 \mathrm{rpm}$, at $25^{\circ} \mathrm{C}$

These data are given in chronological order.

\begin{tabular}{|c|c|c|c|c|c|c|c|}
\hline \multicolumn{2}{|c|}{ Sample } & \multicolumn{6}{|c|}{ Coefficient of friction at $3 \mathrm{rpm}$, after- } \\
\hline Bearing & Shaft & $0 \mathrm{hr}$ & $1 \mathrm{hr}$ & $2 \mathrm{hr}$ & $4 \mathrm{hr}$ & $6 \mathrm{hr}$ & $8 \mathrm{hr}$ \\
\hline 101 & $\left\{\begin{array}{l}\mathrm{M} \\
\mathrm{D} 2 \ldots \\
440 \mathrm{C} \ldots \\
\mathrm{D} 3 \ldots \\
\mathrm{M} \\
\mathrm{D} 2 \ldots\end{array}\right.$ & $\begin{array}{l}0.06 \\
.10 \\
.10 \\
.10 \\
.08 \\
.09\end{array}$ & $\begin{array}{l}0.09 \\
.20 \\
.13 \\
.17 \\
.11 \\
.11\end{array}$ & $\begin{array}{r}0.11 \\
.23 \\
.14 \\
.17 \\
.11 \\
.14\end{array}$ & $\begin{array}{l}0.12 \\
.15 \\
.15 \\
.12 \\
.16\end{array}$ & $\begin{array}{r}0.12 \\
.15 \\
.15 \\
.13 \\
.16\end{array}$ & $\begin{array}{l}0.13 \\
-.15 \\
.15 \\
.13 \\
.15\end{array}$ \\
\hline $202 \mathrm{c}$ & $\left\{\begin{array}{l}440 \mathrm{C} \ldots \ldots \\
\mathrm{D} 3 \ldots \ldots \\
\mathrm{M} \\
\mathrm{D} 2 \ldots \ldots\end{array}\right.$ & $\begin{array}{l}.06 \\
.08 \\
.07 \\
.08\end{array}$ & $\begin{array}{l}.07 \\
.10 \\
.19 \\
.12\end{array}$ & $\begin{array}{l}.07 \\
.10 \\
.27 \\
.15\end{array}$ & $\begin{array}{l}.09 \\
.12 \\
.32 \\
.20\end{array}$ & $\begin{array}{l}.12 \\
.15 \\
.32 \\
.23\end{array}$ & $\begin{array}{l}.15 \\
.22 \\
.33 \\
.25\end{array}$ \\
\hline 215 & $\left\{\begin{array}{l}\mathrm{M}_{\ldots} \\
\mathrm{D} 2 \\
440 \mathrm{C} \ldots \\
\mathrm{D} 3 \\
440 \mathrm{C} \ldots\end{array}\right.$ & $\begin{array}{l}.08 \\
.16 \\
.22 \\
.20 \\
.17\end{array}$ & $\begin{array}{l}19 \\
.19 \\
.17 \\
.20 \\
.18\end{array}$ & $\begin{array}{l}17 \\
.18 \\
.15 \\
.16 \\
.15\end{array}$ & $\begin{array}{l}.15 \\
.15 \\
.15 \\
.13 \\
.14\end{array}$ & $\begin{array}{r}.14 \\
.13 \\
-.12 \\
.13\end{array}$ & $\begin{array}{l}13 \\
.13 \\
.17 \\
.11 \\
.13\end{array}$ \\
\hline 401 & $\left\{\begin{array}{l}\mathrm{D} 2 \\
440 \mathrm{C} \ldots \\
\mathrm{D} 3 \ldots \\
\mathrm{M} \ldots\end{array}\right.$ & $\begin{array}{l}.16 \\
.20 \\
.20 \\
.24\end{array}$ & $\begin{array}{l}.23 \\
.24 \\
.27 \\
.29\end{array}$ & $\begin{array}{l}.25 \\
.24 \\
.28 \\
.33\end{array}$ & $\begin{array}{l}.30 \\
.25 \\
.29 \\
.36\end{array}$ & $\begin{array}{l}.34 \\
.25 \\
.30 \\
.36\end{array}$ & $\begin{array}{l}.34 \\
.26 \\
.30 \\
.34\end{array}$ \\
\hline $\begin{array}{l}215 \\
202 c \\
101 \\
401\end{array}$ & $\mathrm{C} 40 \ldots$ & $\begin{array}{l}.04 \\
.03 \\
.06 \\
.22\end{array}$ & $\begin{array}{l}.10 \\
.09 \\
.07 \\
.25\end{array}$ & $\begin{array}{l}.11 \\
.09 \\
.08 \\
.26\end{array}$ & $\begin{array}{l}.13 \\
.06 \\
.10 \\
.27\end{array}$ & $\begin{array}{l}.14 \\
.06 \\
.11 \\
.27\end{array}$ & $\begin{array}{l}.13 \\
.07 \\
.11 \\
.27\end{array}$ \\
\hline
\end{tabular}

\subsection{Bearing-Storage Results}

With the apparatus and procedure previously described, the effect of storage on starting friction and corrosion was investigated with 6 typical oil-free bearing materials on each of 3 different shafts. The shafts were an oil-hardening nondeforming tool steel (O2), an oil-hardening, high-carbon, high-chromium tool steel (D3), and $440 \mathrm{C}$ stainless steel; the average values of surface roughness as measured by a profilometer before starting the test were 3,4 , and $1 \mu$ in., respectively.

The data for the storage test are given in table 7 .

TABLE 7. Effect of 10 months of storage on the coefficient of static friction, for various bearing and shaft materials

\begin{tabular}{|c|c|c|c|c|}
\hline \multicolumn{2}{|r|}{ Sample } & \multicolumn{2}{|c|}{$\begin{array}{l}\text { Coefficient of } \\
\text { static friction }\end{array}$} & \multirow{2}{*}{ Remarks } \\
\hline Bearing & Shaft & New & $\begin{array}{l}\text { After } 10 \\
\text { months }\end{array}$ & \\
\hline 222 & $\left\{\begin{array}{l}\mathrm{O} 2 \\
\mathrm{~T} 2 \\
440 \mathrm{C}\end{array}\right.$ & $\begin{array}{r}0.09 \\
.12 \\
.11\end{array}$ & $\begin{array}{r}0.15 \\
.17 \\
.17\end{array}$ & $\begin{array}{c}\text { No rust. } \\
\text { Do. } \\
\text { Do. }\end{array}$ \\
\hline 231 & (1) & $\begin{array}{l}.18 \\
.13 \\
.12\end{array}$ & $\begin{array}{l}.17 \\
.17 \\
.17\end{array}$ & $\begin{array}{l}\text { Do. } \\
\text { Do. } \\
\text { Do. }\end{array}$ \\
\hline $237 \mathrm{a}$ & - & $\begin{array}{l}.18 \\
.18 \\
.13\end{array}$ & $\begin{array}{l}.23 \\
.23 \\
.23\end{array}$ & $\begin{array}{l}\text { Do. } \\
\text { Do. } \\
\text { Do. }\end{array}$ \\
\hline & (O2-- & .18 & 1. $7+$ & Journal badly \\
\hline 238 & (n) & $\begin{array}{l}.12 \\
.14\end{array}$ & $\begin{array}{l}1.7+ \\
0.90\end{array}$ & $\begin{array}{l}\text { Journal rusted. } \\
\text { Do. }\end{array}$ \\
\hline 401 & $\left\{\begin{array}{l}\mathrm{O} 2 \ldots \\
\mathrm{T} 3 \\
440 \mathrm{C}\end{array}\right.$ & $\begin{array}{l}.17 \\
.18 \\
.20\end{array}$ & $\begin{array}{l}.17 \\
.20 \\
.18\end{array}$ & $\begin{array}{c}\text { No rust. } \\
\text { Do. } \\
\text { Do. }\end{array}$ \\
\hline 605 & - & $\begin{array}{l}.10 \\
.09 \\
.10\end{array}$ & $\begin{array}{l}.16 \\
.19 \\
.22\end{array}$ & $\begin{array}{l}\text { Do. } \\
\text { Do. } \\
\text { Do. }\end{array}$ \\
\hline
\end{tabular}

With bearing sample 231 on D3 and 440C shafts, and samples $222,237 \mathrm{a}$, and 238 on each shaft, the static friction increased during the 10 months of storage, the range of increase being from 28 to 77 percent. With sample 231 on shaft $\mathrm{O} 2$ and sample 401 on each shaft, within the accuracy of the data, there was no change in friction during storage. With the sample of bearing bronze (No.605), included for comparative purposes, the increase in friction ranged from 60 to 120 percent. With sample 238 (PTFE + molybdenum) there was a very great increase in friction, resulting from corrosion on the shafts; in those areas (journals) of the shafts enclosed by this bearing material, the $\mathrm{O} 2$ journal was covered with rust and the journals of the other two shafts were spotted with rust. No corrosion was observed on any of the shafts in other bearing positions. There was considerable rust on the stevel housings for bearings 238, and a slight amount of rust on the machined faces of the other bearing housings. On the faces in contact with bearings 238 the brass collars were discolored by corrosion. There was no abnormal discoloration on any of the other brass collars. 
The sample 238 bearings used in these tests were machined and installed within 2 weeks after the preparation of this sample of material. Strong odors were emitted from the various samples of PTFE plus molybdenum for several weeks after fusing. Previous experience with new bearings in timepieces, and with pieces of steel in sample jars, indicated that freshly prepared samples of this type might cause corrosion. However, after aging several months, samples no longer caused corrosion of the steel in the jars with the samples. It is probable that storage at an elevated temperature would decrease the period of aging that seems necessary to eliminate the corrosive tendency of this type of material.

\subsection{Bearing-Wear Results}

\section{a. Rotating Journals}

Wear data were obtained with 2,000-g loads on bearings that were $1 / 2$ in. long with $\frac{1}{4}$ in. bores, corresponding to $35 \mathrm{psi}$ on the projected area. Most of the data were obtained with 303 stainless-steel journals operating at 15 and $150 \mathrm{rpm}$, but some data were obtained with other types of steel used for the journals and some data were obtained at 700 and $1,800 \mathrm{rpm}$. These data are given in table 8 , in terms of the number of hours of operation for 0.005 in. of radial wear on the loaded side, computed from the wear rates in milligrams per hour and the densities of the samples. An initial diametral clearance of 0.005 in. was assumed in making these computations; and the radial wear of $0.005 \mathrm{in}$. would increase this to $0.010 \mathrm{in}$. in the hours given in the table. These computed hours of operation for $0.005 \mathrm{in}$. of wear should be considered approximations, because the initial clearance in the tests varied from $0.005 \mathrm{in}$. and the bearing deformation resulting from the load was not considered.

TABLE 8. Rate of wear for various bearing materials, with 1/4in.-diameter shafts, at room temperature, with 2,000-g load

\begin{tabular}{|c|c|c|c|c|c|c|c|}
\hline \multicolumn{2}{|c|}{ Sample } & \multirow{2}{*}{$\begin{array}{l}\text { Length } \\
\text { of test } \\
\text { at } 150 \\
\text { rpm }\end{array}$} & \multicolumn{4}{|c|}{$\begin{array}{l}\text { Computed number of hours for } \\
0.005 \text {-in. radial wear }\end{array}$} & \multirow{2}{*}{$\begin{array}{l}\text { Rating a } \\
\text { at } 150 \\
\text { rpm }\end{array}$} \\
\hline Shaft & $\begin{array}{l}\text { Bear- } \\
\text { ing }\end{array}$ & & $15 \mathrm{rpm}$ & $150 \mathrm{rpm}$ & $700 \mathrm{rpm}$ & $\begin{array}{l}1,800 \\
\text { rpm }\end{array}$ & \\
\hline 303 & $\left\{\begin{array}{l}101 \\
101 \\
102 \\
102 \\
103\end{array}\right.$ & $\begin{array}{c}h r \\
5 \\
53 \\
31 \\
53 \\
72\end{array}$ & $\begin{array}{c}h r \\
1,400 \\
1,340 \\
-1,440\end{array}$ & $\begin{array}{r}h r \\
25 \\
91 \\
116 \\
134 \\
103\end{array}$ & \begin{tabular}{c}
$h r$ \\
\hdashline- \\
$-\cdots$
\end{tabular} & $\begin{array}{c}h r \\
-\cdots \\
-\cdots \\
-\cdots \\
\cdots--\end{array}$ & $\begin{array}{l}5 \\
5 \\
4 \\
4 \\
4\end{array}$ \\
\hline 303 & $\begin{array}{l}103 \mathrm{a} \\
103 \mathrm{~b} \\
104\end{array}$ & $\begin{array}{c}95 \\
-603\end{array}$ & $\begin{array}{l}1,160 \\
1,570\end{array}$ & $\begin{array}{r}99 \\
-360\end{array}$ & - n & 27 & 5 \\
\hline 303 & $\begin{array}{l}201 \\
202 \\
202 \mathrm{a} \\
202 \mathrm{~b} \\
202 \mathrm{c}\end{array}$ & $\begin{array}{l}332 \\
483 \\
144 \\
237 \\
261\end{array}$ & $\begin{array}{c}95,400 \\
100,000+ \\
63,400 \\
54,400 \\
100,000+\end{array}$ & $\begin{array}{c}12,700 \\
100,000+ \\
755 \\
1,550 \\
1,050\end{array}$ & 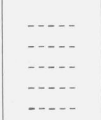 & $\begin{array}{l}-\ldots . \\
-\cdots \\
-\cdots \\
-\cdots \\
-\cdots\end{array}$ & $\begin{array}{l}2 \\
1 \\
4 \\
3 \\
3\end{array}$ \\
\hline 303 & $\begin{array}{l}204 \mathrm{a} \\
205 \\
206 \\
206 \mathrm{a} \\
207\end{array}$ & $\begin{array}{r}332 \\
438 \\
166 \\
525 \\
76\end{array}$ & $\begin{array}{r}45,700 \\
2,230 \\
30,500 \\
18,200 \\
2,050\end{array}$ & $\begin{array}{r}12,200 \\
910 \\
480 \\
1,820 \\
182\end{array}$ & 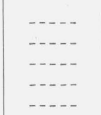 & $\begin{array}{l}-. .- \\
-\ldots \\
-\ldots- \\
-\ldots-\end{array}$ & $\begin{array}{l}2 \\
4 \\
4 \\
3 \\
4\end{array}$ \\
\hline 303 & $\begin{array}{l}208 \\
208 \mathrm{a} \\
209 \\
210 \\
211\end{array}$ & $\begin{array}{l}260 \\
507 \\
169 \\
378 \\
190\end{array}$ & $\begin{array}{r}8,000 \\
9,690 \\
58,100 \\
58,100 \\
19,100\end{array}$ & $\begin{array}{r}1,280 \\
1,820 \\
3,710 \\
6,020 \\
119\end{array}$ & $\begin{array}{l}1,340 \\
2,050\end{array}$ & $\begin{array}{l}-\cdots \\
-\cdots \\
-\cdots \\
-\cdots\end{array}$ & $\begin{array}{l}3 \\
3 \\
3 \\
3 \\
4\end{array}$ \\
\hline
\end{tabular}

TABLE 8. Rate of wear for various bearing materials, with $1 / 4^{-}$ in.-diameter shafts, at room temperature, with 2,000-g loadContinued

\begin{tabular}{|c|c|c|c|c|c|c|c|}
\hline \multicolumn{2}{|c|}{ Sample } & \multirow{2}{*}{$\begin{array}{l}\text { Length } \\
\text { of test } \\
\text { at } 150 \\
\text { rpm }\end{array}$} & \multicolumn{4}{|c|}{$\begin{array}{c}\text { Computed number of hours for } \\
0.005 \text {-in. radial wear }\end{array}$} & \multirow{2}{*}{$\begin{array}{c}\text { Ratinga } \\
\text { at } 150 \\
\text { rpm }\end{array}$} \\
\hline Shaft & $\begin{array}{l}\text { Bear- } \\
\text { ing }\end{array}$ & & $15 \mathrm{rpm}$ & $150 \mathrm{rpm}$ & $700 \mathrm{rpm}$ & $\begin{array}{l}1,800 \\
\text { rpm }\end{array}$ & \\
\hline 303 & $\left\{\begin{array}{l}212 \\
213 \\
214 \\
214 \\
215\end{array}\right.$ & \begin{tabular}{c}
$h r$ \\
166 \\
166 \\
213 \\
\hdashline 385
\end{tabular} & $\begin{array}{c}h r \\
5,790 \\
10,600 \\
63,100 \\
11,400\end{array}$ & \begin{tabular}{r}
\multicolumn{1}{c}{$h r$} \\
236 \\
2,120 \\
11,300 \\
8,700
\end{tabular} & $\begin{array}{c}h r \\
-48 \\
286 \\
93 \\
11,400\end{array}$ & $\begin{array}{l}h r \\
-1,220\end{array}$ & $\begin{array}{c}4 \\
3 \\
2 \\
3\end{array}$ \\
\hline $\begin{array}{l}440 \mathrm{C} \\
\text { D3 } \\
\text { C40 } \\
303\end{array}$ & $\begin{array}{l}215 \\
215 \\
215 \\
215 \mathrm{a} \\
216\end{array}$ & $\begin{array}{l}331 \\
216 \\
336 \\
221 \\
361\end{array}$ & $\begin{array}{c}1,340 \\
100,000+\end{array}$ & $\begin{array}{r}1,880 \\
1,830 \\
3,810 \\
187 \\
24,900\end{array}$ & $\begin{array}{c}\cdots \\
-\cdots \\
-\cdots-1 \\
-5,170\end{array}$ & $\begin{array}{r}247 \\
415 \\
507 \\
-6,050\end{array}$ & $\begin{array}{l}3 \\
3 \\
3 \\
4 \\
2\end{array}$ \\
\hline $\begin{array}{l}440 \mathrm{C} \\
\text { D3 } \\
303\end{array}$ & $\left\{\begin{array}{l}216 \\
216 \\
217 \\
218 \\
218 \mathrm{a}\end{array}\right.$ & $\begin{array}{l}427 \\
234 \\
313 \\
315 \\
334\end{array}$ & $\begin{array}{l}18,900 \\
26,100 \\
22,800\end{array}$ & $\begin{array}{r}30,400 \\
10,500 \\
2,070 \\
14,000 \\
12,200\end{array}$ & 2,150 & $\begin{array}{l}3,860 \\
1,960 \\
-\cdots \\
-\cdots\end{array}$ & $\begin{array}{l}2 \\
2 \\
3 \\
2 \\
2\end{array}$ \\
\hline 303 & $\left\{\begin{array}{l}219 \\
220 \\
220 \mathrm{a} \\
221 \\
222\end{array}\right.$ & $\begin{array}{l}629 \\
335 \\
405 \\
331 \\
331\end{array}$ & $\begin{array}{c}31,800 \\
100,000+ \\
100,000+ \\
6,090 \\
88,600\end{array}$ & $\begin{array}{r}11,900 \\
1,630 \\
8,900 \\
2,430 \\
88,600\end{array}$ & \begin{tabular}{c}
21 \\
$\cdots$ \\
\hdashline 397 \\
$\cdots$
\end{tabular} & 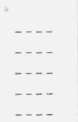 & $\begin{array}{l}2 \\
3 \\
3 \\
3 \\
2\end{array}$ \\
\hline 303 & $\left\{\begin{array}{l}223 \\
224 \\
225 \\
226\end{array}\right.$ & $\begin{array}{l}602 \\
599 \\
600 \\
331\end{array}$ & $\begin{array}{c}100,000+ \\
100,000+ \\
83,000 \\
20,700\end{array}$ & $\begin{array}{l}12,000 \\
49,800 \\
35,600 \\
27,600\end{array}$ & $\begin{array}{r}5,120 \\
8,300 \\
2,490 \\
41,500\end{array}$ & $\begin{array}{l}1,720 \\
3,110 \\
6,730\end{array}$ & $\begin{array}{l}2 \\
2 \\
2 \\
2\end{array}$ \\
\hline D3 & 226 & $\ldots$ & - & ..... & $\ldots$ & 1,240 & $\ldots$ \\
\hline 303 & $\left\{\begin{array}{l}227 \mathrm{a} \\
228 \\
229 \\
230 \\
231\end{array}\right.$ & $\begin{array}{r}20 \\
235 \\
167 \\
102 \\
98\end{array}$ & $\begin{array}{r}113 \\
60,800 \\
60,800 \\
13,000 \\
21,500\end{array}$ & $\begin{array}{r}35 \\
7,020 \\
10,100 \\
16,600 \\
203\end{array}$ & $\begin{array}{r}2,430 \\
2,100 \\
1,400 \\
99\end{array}$ & $\begin{array}{c}962 \\
704 \\
-\end{array}$ & $\begin{array}{l}5 \\
3 \\
2 \\
2 \\
4\end{array}$ \\
\hline 303 & $\left\{\begin{array}{l}232 \\
233 \\
234 \\
234 \mathrm{a} \\
235\end{array}\right.$ & $\begin{array}{l}102 \\
102 \\
477 \\
576 \\
449\end{array}$ & $\begin{array}{r}4,450 \\
3,380 \\
\\
\end{array}$ & $\begin{array}{r}1,660 \\
4,150 \\
4,810 \\
19,200 \\
11,400\end{array}$ & $\begin{array}{c}166 \\
553 \\
---- \\
--- \\
-\cdots-\end{array}$ & $\begin{array}{c}\cdots \\
\cdots 522 \\
1,010 \\
2,340\end{array}$ & $\begin{array}{l}3 \\
3 \\
3 \\
2 \\
2\end{array}$ \\
\hline D3 & 235 & & & & ..... & 2 & \\
\hline 303 & 236 & 486 & . & 1,010 & $\ldots$ & 445 & 3 \\
\hline D3 & $\begin{array}{r}236 \\
236\end{array}$ & $\begin{array}{l}525 \\
700\end{array}$ & ....... & 456 & $\ldots$ & 237 & 4 \\
\hline 303 & $\left\{\begin{array}{l}230 \\
236\end{array}\right.$ & 1500 & , n..... & $\begin{array}{l}1,830 \\
1,010\end{array}$ & - n & -.. & $\begin{array}{l}3 \\
3\end{array}$ \\
\hline 303 & $\left\{\begin{array}{l}236 \\
236 \\
236 \\
236 \\
237\end{array}\right.$ & $\begin{array}{r}700 \\
1500 \\
700 \\
1500 \\
486\end{array}$ & - & $\begin{array}{r}1,070 \\
795 \\
1,520 \\
1,010 \\
507\end{array}$ & 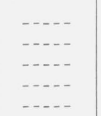 & \begin{tabular}{c|}
$\cdots--$ \\
$\cdots \cdots$ \\
--- \\
589
\end{tabular} & $\begin{array}{l}3 \\
4 \\
3 \\
3 \\
4\end{array}$ \\
\hline $\begin{array}{l}303 \\
440 \mathrm{C} \\
\mathrm{C} 40\end{array}$ & $\left\{\begin{array}{l}237 \mathrm{a} \\
237 \mathrm{~b} \\
237 \mathrm{c} \\
237 \mathrm{c} \\
237 \mathrm{c}\end{array}\right.$ & $\begin{array}{l}486 \\
144 \\
267 \\
458 \\
480\end{array}$ & 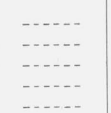 & $\begin{array}{r}415 \\
507 \\
2,220 \\
870 \\
1,220\end{array}$ & 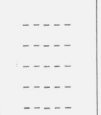 & $\begin{array}{l}760 \\
570 \\
140 \\
130 \\
140\end{array}$ & $\begin{array}{l}4 \\
4 \\
3 \\
4 \\
3\end{array}$ \\
\hline $\begin{array}{l}303 \\
440 \mathrm{C} \\
\text { D3 } \\
\text { C40 } \\
303\end{array}$ & $\begin{array}{l}238 \\
238 \\
238 \\
238 \\
238 \mathrm{a}\end{array}$ & $\begin{array}{l}476 \\
600 \\
312 \\
310 \\
478\end{array}$ & on. & $\begin{array}{c}26,800 \\
1,660 \\
3,750 \\
100,000+ \\
29,900\end{array}$ & $\begin{array}{l}\ldots . . . \\
\ldots \ldots \\
\cdots \cdots \\
\cdots \cdots\end{array}$ & $\begin{array}{r}94 \\
1,510 \\
1,240 \\
21 \\
30\end{array}$ & $\begin{array}{l}2 \\
3 \\
3 \\
1 \\
2\end{array}$ \\
\hline 303 & $238 \mathrm{~b}$ & 390 & ...... & 31,900 & ..... & 42 & 2 \\
\hline 303 & 304 & 1 & ...... & 52 & .... & ...- & 5 \\
\hline 303 & $\left\{\begin{array}{l}401 \\
402 \\
403 \\
404\end{array}\right.$ & $\begin{array}{l}597 \\
405 \\
403 \\
338\end{array}$ & $\begin{array}{r}14,600 \\
19,400 \\
41,500 \\
5,740\end{array}$ & $\begin{array}{r}13,300 \\
3,230 \\
5,810 \\
313\end{array}$ & $\begin{array}{c}334 \\
\ldots \ldots \\
\ldots\end{array}$ & -.. & $\begin{array}{l}2 \\
3 \\
3 \\
4\end{array}$ \\
\hline 303 & $\left\{\begin{array}{l}605 \\
606 \\
609 \\
611 \\
612\end{array}\right.$ & $\begin{array}{l}\quad 4 \\
0.8 \\
266 \\
170 \\
143\end{array}$ & 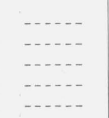 & $\begin{array}{c}50 \\
0.9 \\
11,600 \\
5,220 \\
630\end{array}$ & $\begin{array}{l}\ldots . . . \\
\cdots \cdots \\
\cdots \cdots\end{array}$ & $\begin{array}{r}513 \\
166 \\
3\end{array}$ & $\begin{array}{l}5 \\
5 \\
2 \\
3 \\
4\end{array}$ \\
\hline
\end{tabular}

a 1: $100,000+\mathrm{hr}$, excellent.

2: 10,001 to $100,000 \mathrm{hr}$, very good

3: 1,001 to $10,000 \mathrm{hr}$, good

4: 101 to $1,000 \mathrm{hr}$, fair.

5: 0 to $100 \mathrm{hr}$, poor. 
In general, the duration of a test was short compared to the hours computed for 0.005 -in. radial wear. Included in table 8 are the durations of the tests at $150 \mathrm{rpm}$. Special tests were made with sample 236 to get indications of the effect of duration of tests and the effect of journal roughness. In these special tests, three bearings (sample 236) with 0.005-in. initial clearance were tested on three 303 stainless-steel journals with roughness values of 2,8 , and 16 in., as measured with a profilometer. The wear was determined for $700 \mathrm{hr}$ and then for $1,500 \mathrm{hr}$, after running an additional $800 \mathrm{hr}$. In this range of roughness, there was no trend for variation of wear with roughness; but there was a trend toward higher rate of wear with the longer period of operation. For these special tests the computed hours of operation for 0.005 -in. wear on the loaded side ranged from 795 to $1,830 \mathrm{hr}$, which may be compared with $1,010 \mathrm{hr}$ computed from a previous test with $486 \mathrm{hr}$ of duration.

In table 8, ratings are given for the wear resistance of the bearing for each test at $150 \mathrm{rpm}$. Ratings 1 and 2 are given for computed hours of operation above 100,000 and 10,000 , and are considered excellent and very good, respectively. Rating 3 is given for operation between 1,001 and $10,000 \mathrm{hr}$, and is considered good.

TABLE 9. Wear for various bearing materials, with 1/8-in. diameter shafts, at room temperature, with 1,000-g load; shafts oscillating, amplitude $=0.5$ radian, frequency $=3 \mathrm{cps}$

\begin{tabular}{|c|c|c|c|c|c|c|c|}
\hline \multicolumn{2}{|c|}{ Sample } & \multirow{2}{*}{$\begin{array}{c}\text { Time } \\
\text { run }\end{array}$} & \multicolumn{2}{|c|}{$\begin{array}{c}\text { Bearing loss } \\
\text { in weight }\end{array}$} & \multicolumn{2}{|c|}{$\begin{array}{l}\text { Condition of journals at end of } \\
\text { tests }\end{array}$} & \multirow{2}{*}{$\begin{array}{l}\text { Rat- } \\
\text { ing a }\end{array}$} \\
\hline Shaft & $\begin{array}{c}\text { Bear- } \\
\text { ing }\end{array}$ & & Front & Rear & Front & Rear & \\
\hline 303 & $\left\{\begin{array}{l}101 \\
202 \mathrm{c} \\
209 \\
210 \\
214\end{array}\right.$ & Days & $\left\{\begin{array}{l}m g \\
0.8 \\
.0 \\
.0 \\
.1 \\
.1\end{array}\right.$ & $\begin{array}{l}m g \\
9.1 \\
0.0 \\
.4 \\
.1 \\
.1\end{array}$ & $\begin{array}{l}\text { Very good } \\
\text { Good } \\
\text { Fair } \\
\text { do }\end{array}$ & $\begin{array}{l}\text { Scored } \\
\text { Good } \\
\text { Fair } \\
\\
\end{array}$ & $\begin{array}{l}5 \\
1 \\
3 \\
2 \\
2 \\
2\end{array}$ \\
\hline 303 & $\left\{\begin{array}{l}215 \\
219 \\
221 \\
222 \\
224\end{array}\right.$ & 60 & $\begin{array}{r}.1 \\
.2 \\
1.0 \\
0.1 \\
.1\end{array}$ & $\begin{array}{l}.3 \\
.2 \\
.6 \\
.2 \\
.2\end{array}$ & $\begin{array}{l}\text { Very good } \\
\text { Good } \\
\text { Scored } \\
\text { Very good } \\
\text { Good }\end{array}$ & $\begin{array}{l}\text { Very good } \\
\text { Good } \\
\text { Fair do }\end{array}$ & $\begin{array}{l}2 \\
2 \\
4 \\
2 \\
2\end{array}$ \\
\hline 303 & $\left\{\begin{array}{l}234 \\
234 \mathrm{a} \\
237 \\
401 \\
403\end{array}\right.$ & 60 & $\begin{array}{l}.1 \\
.1 \\
.4 \\
.6 \\
.1\end{array}$ & $\begin{array}{r}.1 \\
.0 \\
.4 \\
1.0 \\
0.2\end{array}$ & $\begin{array}{l}\text { Very good } \\
\text { Good } \\
\text { Very good } \\
\text { Fair } \\
\text { Good }\end{array}$ & $\begin{array}{c}\text { Very good } \\
\text { do do } \\
\text { Fair } \\
\text { Good }\end{array}$ & $\begin{array}{l}1 \\
1 \\
3 \\
4 \\
2\end{array}$ \\
\hline $440 \mathrm{C}$ & $\left\{\begin{array}{l}202 \mathrm{c} \\
214 \\
234 \mathrm{a} \\
401\end{array}\right.$ & 60 & $\left\{\begin{array}{l}3 \\
.1 \\
.1 \\
.1\end{array}\right.$ & $\begin{array}{l}.4 \\
.1 \\
.1 \\
.4\end{array}$ & $\begin{array}{l}\text { Fair } \\
\text { Good } \\
\text { Very good } \\
\text { Good }\end{array}$ & $\begin{array}{l}\text { Scored } \\
\text { Fair } \\
\text { Very good } \\
\text { Good }\end{array}$ & $\begin{array}{l}4 \\
2 \\
1 \\
3\end{array}$ \\
\hline D3 & $\left\{\begin{array}{l}202 \mathrm{c} \\
214 \\
222 \\
401\end{array}\right.$ & 60 & $\left\{\begin{array}{l}1.9 \\
2.5 \\
0.0 \\
.2\end{array}\right.$ & $\begin{array}{l}1.4 \\
1.6 \\
0.1 \\
.1\end{array}$ & $\begin{array}{l}\text { Scored } \\
\text { Good } \\
\end{array}$ & $\begin{array}{l}\text { Scored } \\
\text { Very good } \\
\text { Good }\end{array}$ & $\begin{array}{l}4 \\
4 \\
1 \\
2\end{array}$ \\
\hline $\mathrm{C} 40$ & $\left\{\begin{array}{l}202 \mathrm{c} \\
214 \\
401\end{array}\right.$ & 60 & $\left\{\begin{array}{l}.6 \\
.5 \\
.0\end{array}\right.$ & $\begin{array}{l}.3 \\
3 \\
.0\end{array}$ & $\begin{array}{l}\text { Fair } \\
\text { Good } \\
. \text { do }\end{array}$ & \begin{tabular}{l}
$\ldots$ do \\
\hdashline \\
\hdashline
\end{tabular} & $\begin{array}{l}3 \\
3 \\
1\end{array}$ \\
\hline $440 \mathrm{C}$ & $\left\{\begin{array}{l}303 \\
605\end{array}\right.$ & \} 10 & $\left\{\begin{array}{r}5.8 \\
23.9\end{array}\right.$ & $\begin{array}{r}5.8 \\
29.0\end{array}$ & Worn slightly & $\begin{array}{l}\text { Worn slightly } \\
\text { do }\end{array}$ & $\begin{array}{l}5 \\
5\end{array}$ \\
\hline D3 & $\left\{\begin{array}{l}303 \\
605\end{array}\right.$ & \} 10 & $\left\{\begin{array}{l}12.1 \\
17.7\end{array}\right.$ & $\begin{array}{l}16.3 \\
16.6\end{array}$ & .... do & $\begin{array}{l}\text { Worn and } \\
\text { scored. }\end{array}$ & $\begin{array}{l}5 \\
5\end{array}$ \\
\hline
\end{tabular}

a 1: excellent; 2: very good; 3: good; 4: fair; 5 : poor.

\section{b. Oscillating Journals}

Wear data were obtained with $1,000-\mathrm{g}$ loads on typical paired bearings, each $1 / 8$ in. long with $1 / 8$-in. bore, with various steel shafts in the modified oscillating display motors. The pressure during the impulse from the solenoid was considerably greater than the 70 psi corresponding to the $1,000-\mathrm{g}$ static load. These data are given in table 9 . In general, the loss in weight of the typical bearings and the condition of the journals after 60 days of operation are given. However, with porous bronze containing molybdenum disulfide (sample 303) and with bearing bronze (sample 605), the friction increased soon afier starting the tests to the extent that a much higher voltage had to be applied to the solenoids to maintain operation and one solenoid burned out due to overloading. Because of this and excessive wear, tests with these two materials were stopped at the end of 10 days. It is of interest that the performance with these two bearing materials (samples 303 and 605) in this machine was very much inferior to any of the other oil-free materials that were tested on it. The rating numbers given in table 9 for each test are based on the bearing wear and the condition of the journals at the end of each test. The numbers 1 to 5 correspond to excellent, very good, good, fair, and poor, respectively.

\section{c. Thrus Bearings With Oscillating Pins}

With the endstone-wear testing machine, wear data were obtained with typical bearing materials and test pins made of typical shaft materials, with $1,000-$ and $1,240-\mathrm{g}$ loads. The data obtained with the $440 \mathrm{C}$ test pins are given in table 10 . For each measured depth of wear (see section 5.4 for method of measuring) the corresponding pressure (pounds per square inch) on the projected area was computed, and these data are included in table 10. At $0.0167 \mathrm{in}$. of wear the diameter of the wear mark, becomes the same as that of the pin $(0.125$ in.), so that for greater depths of wear the pressure does not increase. The average rates of wear per bearing, in inches per year, for each period are given in the table also.

With the diamond endstone there was no wear on the diamond or the pin that could be detected by ordinary means. No flat could be detected on the pin when examined with a 20-power stereomicroscope and when examined with a shadowgraph. No roughness was detected on the diamond, but examination with an interferometer indicated a depression about $17 \mu \mathrm{in}$. deep near the center of the endstone after the 60-day test. On the basis of this test, diamond is rated as excellent for use as endstones.

With PTFE plus molybdenum (sample 202c) and with PTFCE plus PTFE (sample 215) no measurable wear was detected during the last 20 days of operation, and hence these materials are rated very good for use as endstones.

With samples 222 and 401 the rate of wear was low during the last period of operation, and these materials may be rated as good. The relatively wide spread in the data for the carbon plus graphite 
TABLE 10. Wear data for typicai bearing materials, with endstone-wear machine, with 440C hardened steel shafts, 1/8-in. diameter with 1/8-in. radius at ends, at room temperature; shafts oscillating, amplitude $=1.5$ radians, frequency $=1$ cps

\begin{tabular}{|c|c|c|c|c|c|c|}
\hline \multirow{2}{*}{ Sample } & \multirow{2}{*}{$\begin{array}{l}\text { Time } \\
\text { run }\end{array}$} & \multicolumn{2}{|c|}{ 1,000-g load } & \multicolumn{2}{|c|}{1,240 -g load } & \multirow{2}{*}{$\begin{array}{l}\text { A verage } \\
\text { rate of } \\
\text { wear b }\end{array}$} \\
\hline & & $\begin{array}{l}\text { Depth } \\
\text { of wear }\end{array}$ & $\begin{array}{l}\text { Pres- } \\
\text { sure a }\end{array}$ & $\begin{array}{l}\text { Depth } \\
\text { of wear }\end{array}$ & $\begin{array}{l}\text { Pres- } \\
\text { sure a }\end{array}$ & \\
\hline 101 & $\left\{\begin{array}{c}\text { Days } \\
10 \\
20 \\
40 \\
60\end{array}\right.$ & $\begin{array}{c}\text { in. } \\
0.0075 \\
.011 \\
.016 \\
.020\end{array}$ & $\begin{array}{c}p s i \\
385 \\
266 \\
187 \\
180\end{array}$ & $\begin{array}{c}\text { in. } \\
0.0075 \\
.010 \\
.015 \\
.020\end{array}$ & $\begin{array}{c}p s i \\
478 \\
363 \\
247 \\
223\end{array}$ & $\begin{array}{l}\text { in./yr } \\
0.274 \\
.110 \\
.091 \\
.082\end{array}$ \\
\hline 102 & $\begin{array}{l}10 \\
20 \\
40 \\
60\end{array}$ & $\begin{array}{l}.005 \\
.009 \\
.013 \\
.016\end{array}$ & $\begin{array}{l}575 \\
323 \\
228 \\
187\end{array}$ & $\begin{array}{l}.005 \\
.0075 \\
.011 \\
.014\end{array}$ & $\begin{array}{l}711 \\
478 \\
330 \\
263\end{array}$ & $\begin{array}{l}.182 \\
.119 \\
.068 \\
.055\end{array}$ \\
\hline $202 \mathrm{e}$ & $\begin{array}{l}10 \\
20 \\
40 \\
60\end{array}$ & $\begin{array}{l}.001 \\
.0015 \\
.002 \\
.002\end{array}$ & $\begin{array}{l}2,813 \\
1,875 \\
1,418 \\
1,418\end{array}$ & $\begin{array}{l}.001 \\
.0015 \\
.002 \\
.002\end{array}$ & $\begin{array}{l}3,490 \\
2,326 \\
1,758 \\
1,758\end{array}$ & $\begin{array}{l}.036 \\
.018 \\
.009 \\
.000\end{array}$ \\
\hline 215 & $\begin{array}{l}10 \\
20 \\
40 \\
60\end{array}$ & $\begin{array}{l}.0015 \\
.002 \\
.002 \\
.002\end{array}$ & $\begin{array}{l}1,875 \\
1,418 \\
1,418 \\
1,418\end{array}$ & $\begin{array}{l}.002 \\
.002 \\
.002 \\
.002\end{array}$ & $\begin{array}{l}1,758 \\
1,758 \\
1,758 \\
1,758\end{array}$ & $\begin{array}{l}.064 \\
.009 \\
.000 \\
.000\end{array}$ \\
\hline 222 & $\begin{array}{l}10 \\
20 \\
40 \\
60\end{array}$ & $\begin{array}{l}.0015 \\
.0015 \\
.002 \\
.002\end{array}$ & $\begin{array}{l}1,875 \\
1,875 \\
1,418 \\
1,418\end{array}$ & $\begin{array}{l}.0015 \\
.002 \\
.002 \\
.0025\end{array}$ & $\begin{array}{l}2,326 \\
1,758 \\
1,758 \\
1,393\end{array}$ & $\begin{array}{l}.055 \\
.009 \\
.005 \\
.005\end{array}$ \\
\hline 401 & $\begin{array}{l}10 \\
20 \\
40 \\
60\end{array}$ & $\begin{array}{l}.0015 \\
.002 \\
.0035 \\
.004\end{array}$ & $\begin{array}{r}1,875 \\
1,418 \\
818 \\
715\end{array}$ & $\begin{array}{l}.001 \\
.0015 \\
.0015 \\
.0015\end{array}$ & $\begin{array}{l}3,490 \\
2,326 \\
2,326 \\
2,326\end{array}$ & $\begin{array}{l}.046 \\
.018 \\
.014 \\
.005\end{array}$ \\
\hline $\begin{array}{c}604 \\
\text { (Sapphire) }\end{array}$ & $\begin{array}{l}10 \\
20 \\
40 \\
60\end{array}$ & $\begin{array}{l}.004^{\mathrm{c}} \\
.005 \\
.007 \\
.0095\end{array}$ & $\begin{array}{l}715 \\
574 \\
412 \\
311\end{array}$ & - & - & $\begin{array}{l}.146 \text { e } \\
.036 \\
.036 \\
.046\end{array}$ \\
\hline 609 & 10 & .010 & 292 & .016 & 232 & .475 \\
\hline $\begin{array}{c}610 \\
\text { (Diamond) }\end{array}$ & $\begin{array}{l}10 \\
20 \\
40 \\
60\end{array}$ & -..... & 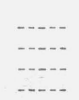 & $\begin{array}{l}.0000 \\
.0000 \\
.0000 \\
.0000\end{array}$ & $\begin{array}{l}139,300 \\
139,300 \\
139,300 \\
139,300\end{array}$ & $\begin{array}{l}.000 \\
.000 \\
.000 \\
.000\end{array}$ \\
\hline 611 & 4 & .031 & 180 & .027 & 233 & 2.65 \\
\hline
\end{tabular}

s Computed pressure on the projected area for each measured depth of wear: excepting diamond, in which case pressure was computed from the elastie deformation of the radius on the end of the steel pin.

b Computed from average wear during each period of time run.

- Wear occurred on end of steel pin instead of on sapphire endstone.

plus silver (sample 401) is believed to be due to a lack of homogeneity in the mixture.

With sapphire (sample 604, unlubricated) a relatively large flat was worn on the end of the test pin, and the rate of wear given in table 10 is for this wear on the pin. However, the sapphire became roughened on part of the rubbing area, and was worn slightly.

With PTFE and with PTFCE the endstone-wear rate was high. With the coatings (samples 609 and 611 ) the tests were stopped after a few days of operation because of excessive wear.

Results obtained when samples 101, 202c, 215, and 401 were tested with pins made of 303 stainless steel, hardened D3 steel, and C40 alloy were similar to those obtained with $440 \mathrm{C}$ stainless-steel pins.

With 303 stainless-steel pins, specimens of tungsten plus molybdenum disulfide plus plastic coating (sample 606) on brass started wearing very rapidly, and the test was stopped at the end of the first day of operation. For comparison, a test with plain brass (sample 607) gave less wear than the coated brass, although wear was excessively great in both cases. Although this coating is advertised as showing no wear when used as a thrust bearing under certain conditions, under the conditions used in these tests its wear resistance was inferior to that of brass.

\subsection{Timepiece-Bearing Results}

The performance of oil-free bearings was investigated in 18 timepieces, including chronometers, clocks, and watches.

For plastics and plastics with fillers, the coefficients of thermal expansion are such that with $1 / 4$-in.-bore bearings subjected to a wide range of temperature, clearances much larger than those commonly used with metallic journal bearings are necessary. However, the percentage of clearance normally used for the relatively small journals in timepieces is such that the above condition presents no problem. Bearings of this type become loose in their housings at low temperature; in order to prevent axial dis placement at low temperatures, these bearings were fitted in brass holders having the inner edges crimped inward slightly to retain the bearings.

In general, the amplitude of the motion of the balance wheels in the clocks and watches fitted with oil-free bearings was considerably less than the normal amplitude in oiled-jewel movements at ordinary temperatures. In most cases, heavier mainsprings were installed to increase the torque about 50 percent to provide more normal motion. However, in the chronometers the original mainsprings were not replaced, because they provided sufficient power for normal motion in these timepieces.

On the basis of the experience with timepieces, it appears that for ship chronometers in normal dial-up position the most severe wear is apt to occur at the upper balance-staff endstones, and for clocks operating in the normal 12:00-up position the most severe wear is apt to occur at the beacings for the balancestaff journals. Also, it is probable that the friction at these points is of major importance.

For watches and clocks, the friction and wear at the pallet stones also appears to be of major importance, and no material has been found to be more satisfactory than sapphire for this application. Unlubricated sapphire pallet stone appears to be satisfactory at ordinary temperatures, but at very low temperatures the addition of a film of a suitable low-temperature oil apparently gives less friction than clean sapphire.

Rusting is apt to occur in unlubricated timepieces, especially at the balance-staff pivots, unless precautions are taken to prevent it. Experience with timepieces in this investigation indicates vapor phase inhibitors, such as dicyclohexylammonium nitrite, are effective in preventing rust. Also, rusting may be prevented by the use of corrosion-resistant materials; no rust was observed with cobalt alloy (C40) pivots.

In general, at ordinary temperatures the timekeeping performance of timepieces with conventional 


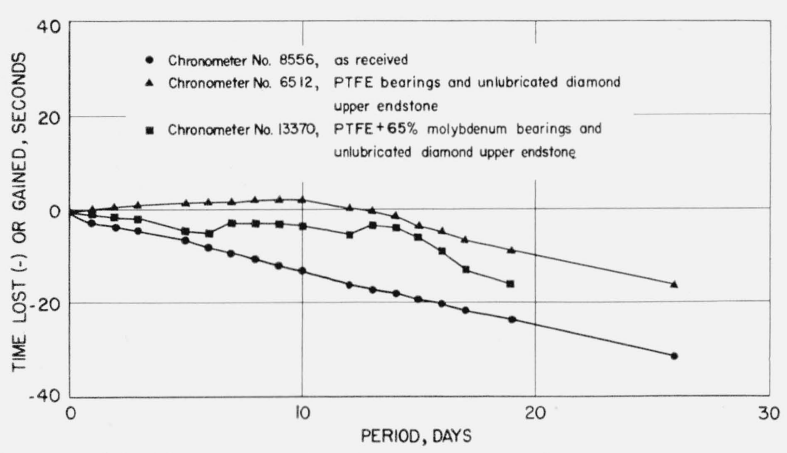

FIGURE 11. Representative time error for chronometers, at room temperature.

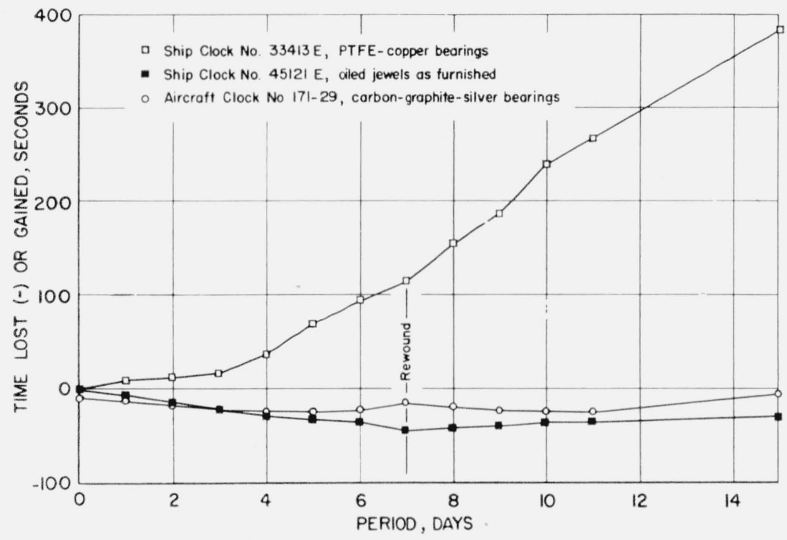

Figure 12. Isochronism curves for 8-day clocks.

lubricated jewels was somewhat superior to that of oil-free timepieces. The degree of this superiority is indicated in figure 11, which shows a plot of time errors for a conventional lubricated chronometer and for two chronometers containing oil-free bearings. However, with less accurate timepieces, the difference in accuracy is of less importance. Typical isochronism curves are given in figure 12 , for a conventional ship clock, a similar clock fitted with PTFE-plus-copper bearings, and an aircraft clock fitted with carbon-graphite-silver bearings.

Representative data for the performance of six timepieces fitted with oil-free bearings at $-60^{\circ} \mathrm{C}$, $+25^{\circ} \mathrm{C}$, and $+75^{\circ} \mathrm{C}$ are given in table 11 . The sapphire pallet stones in the watches and clocks and the mainsprings and other metal-to-metal working parts in these timepieces were lubricated with MIL-O-11734 oil. The size of the heavier mainsprings in the ship clocks was such that, because of the lesser free space in the mainspring barrels and the corresponding lesser number of turns in winding, they "ran down" in about 5 days instead of 8 days. This may account for the stoppage of one clock on the fifth day after winding, as it was nearly run down when it stopped. The range of temperature is beyond that ordinarily compensated for in timepieces, and lack of temperature compensation may account for some of the variation in rate with temperature for chronometer 13370 and clock 33413E. Considering the wide range in temperature, the rates for the other timepieces were not greatly affected by temperature variation.
TABLE 11. Timepiece performance at various ambient temperatures, with oil-free bearings, except for $M I L-O-11734$ oil on pallet stones, mainsprings, and other metal-to-metal parts

\begin{tabular}{|c|c|c|c|c|c|}
\hline \multirow{2}{*}{ Timepiece } & \multicolumn{2}{|c|}{ Oil-free bearings } & \multicolumn{3}{|c|}{ Gain (+) or loss (-) in $24 \mathrm{hr}$} \\
\hline & Sample & $\begin{array}{c}\text { Num- } \\
\text { ber }\end{array}$ & $-60^{\circ} \mathrm{C}$ & $+25^{\circ} \mathrm{C}$ & $+75^{\circ} \mathrm{C}$ \\
\hline $\begin{array}{l}\text { Ship chronometer No. } \\
6512 \text {, dial up, wound } \\
\text { daily. }\end{array}$ & 101 & $10^{\mathrm{a}}$ & $\begin{array}{l}s e c \\
+17 \\
+10 \\
+7 \\
+8 \\
+10\end{array}$ & $\begin{array}{r}s e c \\
-1 \\
-1 / 2 \\
0 \\
0 \\
-1 / 2\end{array}$ & $\begin{array}{l}s e c \\
-40 \\
-20 \\
-14 \\
-13 \\
-9\end{array}$ \\
\hline $\begin{array}{l}\text { Ship chronometer No. } \\
\text { 13370, dial up, wound } \\
\text { daily. }\end{array}$ & $202 \mathrm{c}$ & $10^{a}$ & $\begin{array}{l}-118 \\
-148 \\
-102 \\
-112 \\
-116\end{array}$ & $\begin{array}{r}+1 / 2 \\
0 \\
-1 / 2 \\
-1 \\
-1 / 2\end{array}$ & $\begin{array}{l}+38 \\
+40 \\
+41 \\
+47 \\
+43\end{array}$ \\
\hline $\begin{array}{l}\text { Navigation watch No. } \\
\text { 995-41, } 24: 00 \text { up, wound } \\
\text { daily. }\end{array}$ & 215 & 19 & $\left\{\begin{array}{r}-7 \\
-7 \\
+51 \\
+37 \\
+27\end{array}\right.$ & $\begin{array}{r}+53 \\
+53 \\
+55 \\
+49 \\
+59\end{array}$ & $\begin{array}{l}+58 \\
+69 \\
+60 \\
+86 \\
+85\end{array}$ \\
\hline $\begin{array}{l}\text { Navigation watch No. } \\
\text { 964-42, dial up, wound } \\
\text { daily. }\end{array}$ & 202 & 19 & $\begin{array}{r}-59 \\
-33 \\
-5 \\
-2 \\
-31\end{array}$ & $\begin{array}{r}+1 \\
-3 \\
-10 \\
-16 \\
-4\end{array}$ & $\begin{array}{r}-10 \\
+20 \\
+26 \\
+17 \\
0\end{array}$ \\
\hline $\begin{array}{l}\text { Ship clock No. 33413E, } \\
\text { 12:00 up, } 1 \text { winding. }\end{array}$ & 205 & 9 & $\begin{array}{l}-311 \\
-334 \\
-344 \\
-330 \\
-354\end{array}$ & $\begin{array}{r}+123 \\
+2 \\
-12 \\
-17 \\
-23\end{array}$ & $\begin{array}{l}-143 \\
-35 \\
-101 \\
-200 \\
-200\end{array}$ \\
\hline $\begin{array}{l}\text { Ship clock No. 45121E, } \\
\text { 12:00 up, } 1 \text { winding. }\end{array}$ & 401 & 9 & $\begin{array}{c}+9 \\
+7 \\
+2 \\
+12 \\
\text { Stopped }\end{array}$ & $\begin{array}{r}+52 \\
+31 \\
-3 \\
-15 \\
-12\end{array}$ & $\begin{array}{r}+10 \\
+10 \\
+6 \\
0 \\
+2\end{array}$ \\
\hline
\end{tabular}

a Including 1 diamond and 1 sapphire endstone, unlubricated.

Twelve timepieces fitted with various oil-free bearings were stored in a low-temperature cabinet maintained at $-60^{\circ} \mathrm{C}$. These were running at the start of this test but were not wound during the storage. After 30 days each timepiece was wound while remaining in the low-temperature cabinet; and if it did not start while winding, it was given quick twists in a manner ordinarily used for starting timepieces. The results of this low-temperature test are given in table 12 . The low-priced watch No. 4-52

TABLE 12. Starting ability of timepieces, after winding, at $-60^{\circ} \mathrm{C}$, after 30 days of storage at $-60^{\circ} \mathrm{C}$

\begin{tabular}{|c|c|c|c|c|}
\hline \multirow{2}{*}{ Timepiece } & \multicolumn{2}{|c|}{ Oil-free bearings } & \multirow{2}{*}{$\begin{array}{l}\text { Other } \\
\text { parts }\end{array}$} & \multirow{2}{*}{ Starting ability } \\
\hline & Sample & $\underset{\text { ber }}{\text { Num- }}$ & & \\
\hline $\begin{array}{l}\text { Navigation watch } 964-42 \\
\text { Ship chronometer } 13370 \\
\text { Ship clock } 33413 \mathrm{E} \\
\text { Aircraft clock } 1\end{array}$ & $\begin{array}{l}202 \\
202 \mathrm{c} \\
205 \\
215\end{array}$ & $\begin{array}{r}19 \\
14 \\
9 \\
8\end{array}$ & $\begin{array}{l}\text { (a) } \\
\text { (b) } \\
\text { (a) } \\
\text { (a) }\end{array}$ & $\begin{array}{l}\text { Started. } \\
\text { Do. } \\
\text { Do. } \\
\text { Do. }\end{array}$ \\
\hline $\begin{array}{l}\text { Navigation watch } 995-41 \\
\text { Pocket watch } 4-52 \\
\text { Aircraft clock } 93-29 \\
\text { Aircraft clock } 88-\mathrm{C}-590\end{array}$ & $\begin{array}{l}215 \\
215 \\
222 \\
234 a\end{array}$ & $\begin{array}{r}19 \\
7 \\
12 \\
12\end{array}$ & $\begin{array}{l}\text { (a) } \\
\text { (c) } \\
\text { (a) } \\
\text { (a) }\end{array}$ & $\begin{array}{l}\text { Do. } \\
\text { Would not start. } \\
\text { Started. } \\
\text { Do. }\end{array}$ \\
\hline $\begin{array}{l}\text { Automobile electric clock } \\
\text { KA-494. } \\
\text { Ship chronometer } 6512 \\
\text { Aircraft clock } 171-29 \\
\text { Ship clock } 45121 \mathrm{E}\end{array}$ & $\begin{array}{l}234 \mathrm{a} \\
237 \mathrm{a} \\
401 \\
401\end{array}$ & $\begin{array}{r}4 \\
16 \\
12 \\
9\end{array}$ & $\begin{array}{l}\text { No oil } \\
\text { (b) } \\
\text { (a) } \\
\text { (a) }\end{array}$ & $\begin{array}{l}\text { Do. } \\
\text { Do. } \\
\text { Do. } \\
\text { Would not run. }\end{array}$ \\
\hline
\end{tabular}

a MIL-O-11734 oil applied to pallet stones several months previously.

b MIL-G-7421 grease in mainspring barrel to arbor bearing and inside fusee winding assembly.

- MIL-O-1173: oil on.pallet pins, pallet arbor, and mainspring assembly. 
with oil at places noted in the table would not start, and ship clock No. $45121 \mathrm{E}$ would not continue running after starting several times. All the other timepieces continued running at $-60^{\circ} \mathrm{C}$ after starting. In the watches and clocks having sapphire pallet stones, the stones had been lubricated with MIL-O-11734 oil several months previously, but this is not a nonspreading type as ordinarily used for this application in timepieces. Some time after the low-temperature starting test, the sapphire pallet stones were examined with a 20-power stereomicroscope; no oil appearing as a liquid could be detected, but various colors appearing on the surface of the sapphire indicated a boundary layer of lubricant was present.

It is believed that MIL-O-11734 oil applied to the sapphire pallet stones will provide boundary lubrication for a period of about 2 years. The oil may be applied to the pallet stones in a few minutes, without the disassembly and time that are required for oiling a timepiece throughout in the conventional manner. For current types of aircraft clocks, by removing the movement from the case the oil may be applied to the pallet stones easily in the conventional manner; or after practice, with the movement in the case a small wire may be inserted through the regulator screw plug opening to apply the oil to the teeth of the escape wheel in less than a minute.

Near the end of this project, in aircraft clock No. 26169,6 bearings and 2 endstones, sample 237 a, were used to replace 8 sapphire jewels; and 7 PTFCE bearings (sample 102) were installed in other positions; namely, third, center, intermediate, and fourth wheel upper. In figure 10 it may be seen that the coefficients of friction for these two samples are practically the same at $-60^{\circ} \mathrm{C}$, and that the mean friction for the two samples remains about the same in the temperature range from $-60^{\circ}$ to $+25^{\circ} \mathrm{C}$. This combination of bearings of these materials was tried to minimize the effect of temperature on the total friction in the clock. With the original mainspring (0.008 in. thick) the motion was poor; hence a stronger mainspring (0.011 in. thick) was installed to give more normal motion of the balance wheel. Operation at $-60^{\circ} \mathrm{C}$ with the sapphire pallet stones unlubricated was not satisfactory. After the addition of MIL-O-11734 oil to the pallet stones, the motion at $-60^{\circ} \mathrm{C}$ was only slightly less than at room temperature, although the clock lost several minutes per day at $-60^{\circ} \mathrm{C}$.

\section{Conclusions}

\subsection{Plastics}

The wear-test data and experience with PTFE in an aircraft clock and in a chronometer indicate that this material (without additives) is not suitable for general use as a bearing material because of its tendency to wear, but at very low surface speeds and low unit pressures its wear resistance may be adequate for special applications. The increase in friction at temperatures below $-20^{\circ} \mathrm{C}$ detracts from its usefulness at low temperatures.
The high friction common to PTFCE at ordinary temperatures, and the rates of wear obtained with it in bearings, for a clock balance staff and an endstone for a chronometer balance staff, do not recommend its use as an oil-free bearing material for timepieces. However, its decrease in friction with decrease in temperature makes it useful for special applications at low speeds, such as that described in the last paragraph in section 6.5.

Nylon has been used as a bearing material in certain industrial applications. However, its friction is higher than that of some of the other materials investigated, and its relatively large variation in water content and change in size with change in ambient temperature and humidity are not desirable.

The high-density polyethylene is a relatively new type of polyethylene plastic, and was obtained near the end of the project. The friction with this material was somewhat greater than with PTFE, and the increase in friction with decrease in temperature was greater than that of PTFE. However, the rate of wear at $150 \mathrm{rpm}$ with this polyethylene (sample 104) was less than that of any of the other unfilled plastics tested under similar conditions.

\subsection{Plastics With Fillers}

PTFCE containing 10 to 60 percent of PTFE as a filler is one of the most promising oil-free bearing materials developed during the project. A patent which is pending, covering this type of material, has been assigned to the U.S. Government. This material has some of the hardness characteristics of PTFCE, the frictional characteristics of PTFE, and wear resistance much greater than that of either of these plastics alone. Unfortunately, the fact that its frictional characteristics are similar to those of PTFE detracts from its usefulness at temperatures below $-20^{\circ} \mathrm{C}$.

With the samples of PTFCE containing graphite and molybdenum disulfide (samples 207 and 213, respectively), the friction and the wear were less than with PTFCE; but these dry lubricant additives did not decrease the friction and wear as much as did the PTFE filler.

PTFE containing molybdenum metal powder as a filler is a promising material also, and a patent (No. 2,715,617) covering this type of material has been assigned to the Government. It has good frictional characteristics and exceptionally good wear resistance under certain conditions.

The commercial preparation of PTFE containing fiber glass and pigment (sample 201) has good wear and friction characteristics when used as oil-free bearings with 0.25 -in. bore. However, the relatively large size of some of the glass fibers and the lack of uniformity in the mixture prevent it from being suitable for bearings where the bore is only about $0.005 \mathrm{in}$

The addition of graphite, copper powder, or molybdenum disulfide powder to PTFE (samples 204a, 205, and 206) has a similar effect in reducing wear in 0.25 -in. bearings. However, these commer- 
cial preparations have small pockets of pure plastic similar to those observed in the material with code No. 201.

In general, the addition of a filler to PTFE decreases the wear greatly, but the filler of silver precipitated flowers (sample 203) is an exception. The experience of high wear and high friction at low speeds with a bearing of this material is not understood. It is believed, from microscopic examination, that the silver particles are much less than $1 \mu$ in size but have a great tendency to occur in conglomerations larger than $5 \mu$. Because of the conglomerations, it is possible that the PTFE does not surround and bind the individual silver particles; and the breakup of the conglomerations during testing may cause the high wear and high friction. In this connection, molybdenum metal powder is readily available in particle sizes from 0.5 to $5 \mu$, and this range of particle size appears to be especially suitable for fillers in PTFE compositions for small oil-free bearings.

\subsection{Impregnated Bronze}

Stereomicroscopic examination of the porous bronzes showed some of the pores and the sections of solid bronze to be much larger than the diameters of common balance-staff journals, and this makes the use of impregnated porous bronze impractical for this application. Also, for larger journals, the friction and wear data obtained for porous bronze impregnated with PTFE and with molybdenum. disulfide discourage its use for an oil-free bearing composition, under the conditions that were investigated.

\subsection{Impregnated Carbon}

In general, the metal-impregnated carbon materials that were tested have good friction and wear characteristics. An additional advantage is their low coefficient of thermal expansion, and in some applications their good electrical conductance may be useful. As suggested by the manufacturer, the carbon-grapbite-silver material (sample 401) seemed more promising for use in timepieces than other samples (402, 403, and 404) produced by the same company. The spread in data obtained with this material on the endstone-wear testing machine indicates a lack of homogeneity in the sample; this and the relative coarseness of the structure discourage its use for very small bearings (less than $1 / 16$-in. bore).

\subsection{Miscellaneous}

No material was found to be as satisfactory as diamond for use as a thrust-bearing material under conditions of high load such as occurs at the balanceshaft upper endstone in chronometers. By an X-ray diffraction test for orientation, it was found that the faces of the diamond used in the endstone-wear testing machine and the diamond endstone in chronometer 13370 were within $4^{\circ}$ of being parallel to an octahedron (111) face (cleavage plane). The face of the endstone in chronometer 6512 was found to differ about $22^{\circ}$ from the octahedral (111) plane. It is considered that each of these diamond endstones was very satisfactory for its intended use as a thrust bearing, even without lubrication.

No material was found to be as satisfactory as sapphire for use as pallet stones in timepieces. Sapphire appeared to be suitable for use as unlubricated endstones when the load was relatively light, especially in timepieces normally operating in an upright position. Unlubricated (clean) sapphire hole bearings (jewels) caused rapid wear or rusting of the conventional balance-staff pivots in timepieces.

Boron carbide without lubrication did not appear to be suitable for use as pallet stones or as a journalbearing material.

Under the conditions tested, ordinary brass and bearing bronze conventionally used for making small bushings did not appear suitable for this application without lubrication.

In journal bearings, a fused coating of PTFCE plus graphite gave good resistance to wear but the friction was relatively high. A fused coating of PTFE one-coat enamel gave lower friction, but the resistance to wear was somewhat less than with the above coating. Both of these coatings (samples 609 and 611, respectively) wore rapidly when tested as thrust bearings. Because of the thickness of the coatings ordinarily used and the difficulty in making a uniform coating with a good bond on small parts, the use of coatings of this type does not seem practical for journals or bearings less than $1 / 16$ in. in diameter. However, work at the Naval Research Laboratory [9] indicates that PTFE coatings may be useful for some applications.

The silver amalgam (sample 501) gave exceptionally low friction at room temperature. However, this material was very brittle and the edges of the hole chipped badly during the boring and reaming operations. An amalgam of dental alloy filings was also tried; it was less brittle than the silver amalgam, but the bearing gave increasingly high friction at the start of a test and scuffing of the bearing soon occurred.

Other publications that may be of interest deal with dry bearings suitable for textile mills [10], and with the frictional characteristics of plastics with and without lubrication [11].

The experimental work (mostly static friction tests) during the early part of this investigation was conducted by John Young, who left the Government service in September 1952. 


\section{References}

[1] E. I. duPont de Nemours \& Co., Tech. Serv. Bul. 13 (1949).

[2] M. W. Kellogg Company, Tech. Bul. 2-10-50.

[3] H. S. White and D. Zei, Static friction tests with various metal combinations and special lubricants, J. Research NBS 46, 292 (1951) RP2198.

[4] F. P. Bowden and D. Tabor, The friction and lubrication of solids (Oxford Univ. Press, London, 1950).

[5] MIL-O-11734 Military Specification: Oil, lubricating, synthetic (for mechanical time fuzes).

[6] MIL-L-17353 Military Specification: Lubricating-oil, low temperature, special.

[7] MIL-G-7421 Military Specification: Grease; extreme low temperature.
[8] R. F. King and D. Tabor, The effect of temperature on the mechanical properties and the friction of plastics, Proc. Phys. Soc. (London) [B] 66, 728 (1953).

[9] R. C. Bowers, W. C. Clinton, and W. A. Zisman, Frictional behavior of polyethylene, polytetrafluoroethylene, and halogenated derivatives, Lubrication Eng. 9, 204 (1953).

[10] S. Ricklin and R. R. Miller, Filled Teflon for dry bearings, Materials \& Methods 40, 112 (October 1954).

[11] W. C. Milz and L. B. Sargent, Jr., Frictional characteristics of plastics, Lubrication Eng. 11, 313 (1955).

Washington, January 31, 1956. 